\title{
International Criminal Law and the Violence against Migrants
}

\author{
Ioannis Kalpouzos*
}

(Received 24 February 2020; accepted 03 March 2020)

\begin{abstract}
Should we use the language of international criminal law (ICL) to discuss, analyze, and address Western policies of migration control? Such policies have included or resulted in indefinite and inhumane detention, deportations, including through practices of push- and pull-backs and numerous deaths of migrants attempting to cross land or sea borders. And yet, recourse to ICL's conceptual and rhetorical apparatus, often reserved for "unimaginable atrocities," may seem ill-fitting and an emotive stretch of doctrine. Drawing from international strategic litigation practice on Australian and European policies, this article examines whether the legal concept of crimes against humanity can apply to the deaths, detention, and deportation of migrants, as part and consequence of Western policies of migration control. As migration control policies involve increasingly sophisticated practices of outsourcing and responsibility avoidance, I further ask whether the tools ICL has developed to describe system criminality can trace individual liability against the distance created by such policies. I also inquire into the potential that the transnational nature of migration and the spreading of anti-migration policies have in activating the jurisdiction of courts and the prioritization of the role of the International Criminal Court. Finally, I consider the danger of fetishizing an international punitive approach, before offering some thoughts that aim to bridge a critical approach to international criminal law with its use in meaningful strategic litigation. Throughout the Article, I argue that applying the categories of ICL to Western policies of migration control can contribute to revealing both the potential and the limits of the regime and its institutions, as well as the structures of asymmetry and injustice present both in anti-migration policies and in international criminal law itself.
\end{abstract}

Keywords: Migration control; international criminal law; crimes against humanity; Australia; migrant detention

\section{A. Introduction}

"This issue must be understood as the annihilation of human beings," wrote Behrouz Boochani ${ }^{1}$ from the Manus Island detention camp, at the heart of the Australian regime of migration detention. "It has been nearly five years full of anguish, anguish that has ground everyone down." ${ }^{2}$ His book, No Friend but the Mountains, "smuggled out" from the camp via text messages, manages

${ }^{\star}$ Lecturer in Law, City Law School, City, University of London; Lecturer on Law, Harvard Law School; Co-founder, Global Legal Action Network. I thank the editors of the Special Issue, Cathryn Costello and Itamar Mann, journal editor Nora Markard, as well as Valentina Azarova and Naz K Modirzadeh. The Workshop on "Accountability for Human Rights Violations in Migration Control" held in Oxford on Nov. 10, 2018, that led to the development of this Article was funded by an ERC Starter Grant RefMig (Grant Agreement 716968, PI Cathryn Costello). All errors remain my own.

${ }^{1}$ Behrouz Boochani, “This is Hell Out Here”: How Behrouz Boochani's Diaries Expose Australia's Refugee Shame, THE GuARDIAN (Dec. 3, 2017), https:/www.theguardian.com/world/2017/dec/04/this-is-hell-behrouz-boochani-diaries-exposeaustralia-refugee-shame; see Behrouz Boochani, No Friend but the Mountains: Writing from Manus Prison (2019).

${ }^{2} I d$. Entry of Nov. 2. 
both to convey and to transcend the misery of inhumane and indefinite detention. He has called the Australian policy criminal, a "crime against humanity," for which Australian politicians must and will be held accountable, ${ }^{3}$ a crime that reflects "the deepest form of violence in the world."

Is this true, in law? What would it take for a policy of a developed state aiming to limit and deter migration to its territory to carry such a heavy label? In 2015, in a co-authored article focusing on Greece, ${ }^{5}$ I argued that the practice of immigration detention developed by European democracies, with the cooperation of the European Union's Frontex agency, may very well satisfy the legal definition of a crime against humanity. Such crimes may not easily fit our established imagination of what is an international crime and who is an international criminal. The law has been predominantly applied, and the International Criminal Court (ICC) has been predominantly focused, on "spectacular" violence committed by tyrants and rebels, rather than the "banal" violence which is a seemingly inevitable byproduct of global inequality. Two years later, I participated in the making of a similar argument in the context of advocacy: the submission of a Communication to the Office of the Prosecutor (OTP) of the ICC, on the situation in Australia, Manus Island and Nauru. ${ }^{6}$ We used open source evidence, a recently leaked cache of 2,000 documents, ${ }^{7}$ as well as over 70 interviews with individuals formerly held in the offshore detention centers and others with first-hand knowledge of the facts. ${ }^{8}$ We found that there were reasonable grounds to believe that Australia and its corporate agents had committed acts of unlawful deportation, imprisonment, torture, persecution and other inhumane acts, as part of "a widespread and systematic attack against a civilian population," therefore satisfying the definition of "crimes against humanity" under the Statute. ${ }^{9}$ When it came to the gravity of the situation, which is a criterion of admissibility, ${ }^{10}$ the Communication highlighted the danger of normalizing these practices, with a risk of their further emulation:

[B]ecause [of the Australian policy's] potential to set a precedent, and to normalise subjecting vulnerable refugee populations to inhumane detention practices in order to deter future refugee flows ... [and] the extent that the policies Australia is adopting are taken up by other states, the Australian situation will result in the normalisation of crimes against humanity [and] the

\footnotetext{
${ }^{3}$ See, among many, Behrouz Boochani's comment that "Australia cannot ignore the human crisis in Manus and Nauru. The situation is getting worse day by day, it is a crime against humanity and violation of human rights. I wonder why the international humanitarian organization are silent in the face of these crimes" (May 26, 2019), https://twitter.com/ behrouzboochani/status/1132850690705854464.

${ }^{4}$ Holly Young, This is the Deepest Form of Violence in the World - An Interview with Behrouz Boochani, SPEX (Apr. 10, 2019), https://spex.de/behrouz-boochani-interview-this-is-the-deepest-form-of-violence-in-the-world/.

${ }^{5}$ Ioannis Kalpouzos \& Itamar Mann, Banal Crimes Against Humanity: The Case of Asylum Seekers in Greece, 16 Melbourne J. InT'L L. 1 (2015).

${ }^{6}$ This was submitted by seventeen academic experts in international criminal and refugee law, brought together by the Stanford International Human Rights and Conflict Resolution Clinic and the Global Legal Action Network (GLAN). See Communique to the Office of the Prosecutor of the International Criminal Court Under Article 15 of the Rome Statute, The Situation in Nauru and Manus Island: Liability for Crimes Against Humanity in the Detention of Refugees and Asylum Seekers, https://c5e65ece-003b-4d73-aa76-854664da4e33.filesusr.com/ugd/b743d9_e4413cb72e1646d8bd3e8a8c9a466950. pdf [hereinafter ICC Australia Communication]. For contemporary coverage see Jamie Smyth, Lawyers Urge ICC to Probe Australia over Refugee Abuse Claims, FinANCIAL Times (Feb. 13, 2017), https://www.ft.com/content/cfc1cce8-f193-11e6-87586876151821a6; Ben Doherty, International Criminal Court Told Australia's Detention Regime Could Be a Crime Against Humanity, The GuARDian (Feb. 13, 2017), https://www.theguardian.com/australia-news/2017/feb/13/international-criminalcourt-told-australias-detention-regime-could-be-a-against-humanity; Rebecca Hamilton, Australia's Refugee Policy is a Crime against Humanity, FOREIGN POLICY (Feb. 23, 2017), https://foreignpolicy.com/2017/02/23/australias-refugee-policy-may-beofficially-a-crime-against-humanity/.

${ }^{7}$ See The Nauru Files, https://www.theguardian.com/australia-news/ng-interactive/2016/aug/10/the-nauru-files-the-livesof-asylum-seekers-in-detention-detailed-in-a-unique-database-interactive.

${ }^{8}$ These were conducted and analyzed by the Stanford clinic's students who also contributed to the drafting of the Communication. See ICC Australia Communication, at 2.

${ }^{9} \mathrm{See}$ Rome Statute of the International Criminal Court, art 7, July 17, 1998, 2187 U.N.T.S. 90.

${ }^{10}$ See id. art. $17(1)(\mathrm{d})$.
} 
perception that a widespread and systematic attack against a civilian population may be seen as normal, banal, and potentially acceptable. Australia is no pariah state. It is a relatively wealthy, "Western," democracy. Its actions and policies have an added effect in terms of being influential and being replicated elsewhere, specifically in other states that are receiving refugee flows. ${ }^{11}$

The scholarly and advocacy work attempted to apply the lex lata to particular migration control scenarios, also with a view to understanding what role international criminal law (ICL) can play in framing and addressing it. The institutional response to the advocacy was mixed. The OTP acknowledged receipt ${ }^{12}$ and confirmed it is analyzing the situation. ${ }^{13}$ The Australian Minister of Immigration referred to the communication as a "wacky cause." ${ }^{14}$ Since then, the understanding of the Australian policy as crimes against humanity has spread, leading to other legal actions using the label, ${ }^{15}$ alongside those employing the more moderate tools of human rights or tort law. ${ }^{16}$ As this article is going to press, three years after our submission, ${ }^{17}$ the Office of the Prosecutor responded. In a four-page document, ${ }^{18}$ the OTP found multiple prohibited acts of unlawful imprisonment but did not consider these to constitute crimes against humanity.

Drawing from this practice and scholarly experience, the present article is a reflection on the relationship between migration and ICL. The practices we observed in Greece and Australia are spreading. The model of outsourcing responsibility in the treatment of the "migration crisis," the orchestration of a proactive policy of managing and deterring migration while seeking to keep one's hands clean, has been significantly developed. ${ }^{19}$ Most importantly, the European Union has developed a strategy through both the EU-Turkey deal and the EU/Italy-Libya cooperation for the detention, deportation and deterrence of asylum seekers. ${ }^{20}$ The United States, as well, is using "safe third country" agreements with Latin and Central American counterparts, ${ }^{21}$ alongside inhumane detention policies, to combine outsourcing and deterrence.

\footnotetext{
${ }^{11}$ See ICC Australia Communication, at 115.

${ }^{12}$ Office of the Prosecutor Letter, OTP-CR-65/17 (Feb. 20, 2017), on file with author.

${ }^{13}$ Office of the Prosecutor Letter, OTP-CR-65/17 (Apr. 11, 2017), on file with author.

${ }^{14}$ Kylar Lussikian, Dutton Hits Back at GetUp! Over Asylum Seeker Referral, THE Australian, (Feb. 14, 2017), https://www. theaustralian.com.au/nation/immigration/dutton-hits-back-at-getup-over-asylum-seeker-referral/news-story/ d31e1561c46f942b9a4f5c282c509800.

${ }^{15}$ See Helen Davidson, Australia Subjected Refugees to Crimes against Humanity, Class Actions Allege, THE GUARDIAN (Dec. 9, 2018), https://www.theguardian.com/australia-news/2018/dec/10/australia-subjected-refugees-to-crimes-against-humanity-classactions-allege.

${ }^{16}$ See Belden Norman Namah v. Hon. Rimbink Pato, Minister for Foreign Affairs and others, SC1497, (Apr. 26, 2016, P.N.G.), available at https:/www.documentcloud.org/documents/2812420-Manus-Island-Decision.html\#document/p1; Gabrielle Holly, Transnational Tort and Access to Remedy under the UN Guiding Principles on Business and Human Rights: Kamasee v Commonwealth, 19(1) MeLB. J. INT'L L. 52 (2018).

${ }^{17}$ For a critique of the "unfettered discretion" of the Prosecutor on temporal and other aspects of preliminary examinations see Anni Pues, Towards the Golden Hour? A Critical Examination of the Length of Preliminary Examinations, 15 J. INT'L CRIM. Just. 435 (2017). See also Carsten Stahn, Damned if You Do, Damned if You Don't: Challenges and Critiques of Preliminary Examinations at the ICC, 15 J. INT'L CRIM. JUST. 413 (2017).

${ }^{18}$ Office of the Prosecutor Letter, OTP-CR-65/17 (Feb. 12, 2020), on file with author [hereinafter OTP Response]. The response is identical to one sent to Andrew Wilkie MP, who had also submitted a communication on the situation. For commentary on the response(s) see Kevin Jon Heller, The OTP Lets Australia Off the Hook, OpINIO JuRIS (Feb. 17, 2020), http:// opiniojuris.org/2020/02/17/the-otp-lets-australia-off-the-hook/.

${ }^{19}$ For the emergence and evolution of these policies see Thomas Gammeltoft-Hansen \& James C. Hathaway, NonRefoulement in a World of Cooperative Deterrence, 53 Colum. J. Transnat'L L. 235 (2015).

${ }^{20}$ See Luiza Bialasiewicz, Off-Shoring and Out-Sourcing the Borders of Europe: Libya and EU Border Work in the Mediterranean, 17 Geopolitics 843 (2012), See, more broadly, David S. FitzGerald, Refuge Beyond Reach: How Rich Democracies Repel Asylum SeEKers (2019).

${ }^{21} \mathrm{See}$ Agreement between the Government of the United States of America and the Government of the Republic of Guatemala on Cooperation Regarding the Examination of Protection Claims (Nov. 20, 2019), https://www.federalregister. gov/documents/2019/11/20/2019-25288/agreement-between-the-government-of-the-united-states-of-america-and-thegovernment-of-the-republic.
} 
This Article examines violence against migrants as part of state deterrence policies, coupled with efforts to use outsourcing to avoid responsibility and accountability for this violence, from the perspective of ICL. It does not seek to demonstrate that all such practices constitute international crimes, but asks how thinking about that violence through the prism of ICL both illuminates certain features of the phenomenon of migration control practices and also awakens the potential of ICL. This contribution is a reflection on ICL, its boundaries and its development through strategic litigation.

I proceed in four parts. Firstly, I discuss the expressive labeling power of ICL and the conceptual and doctrinal battlegrounds for its application to migration control (Part B). I start with observing the habitual associations drawn between migration and crime, as reflected in the phenomenon of "crimmigration," and ask what it would mean to reverse them. I then discuss how key ICL categories, and specifically selected prohibited acts-murder, unlawful imprisonment and deportation, and persecution-and contextual elements of crimes against humanity, apply to some migration control practices, although they do not ordinarily, as yet, attract such grave labels. Rather than providing an exhaustive analysis of the legal elements, I aim to isolate the key issues that arise before we can treat actions falling within the state's sovereign right to control migration as international crimes.

Secondly, I examine questions of liability for outsourced migration control in light of ICL's promise to trace responsibility in complex and collective structures and ask whether they can challenge who we can imagine as a perpetrator of international crimes (Part C). Thirdly, I consider how the transnational nature of the phenomenon of migration and the global potential for emulation of violent policies against migration ought to influence the role of judicial institutions, and especially the ICC, in applying its rules on jurisdiction and admissibility (Part D).

Finally, and having so far argued for the potential of ICL's categories and institutions, I consider the danger of fetishizing the legal regime and a punitive approach, before offering some conclusive thoughts that aim to bridge a critical approach to ICL with its use in meaningful strategic litigation (Part E).

\section{B. Labelling Violence Against Migrants}

\section{On the Relation between Migration and Criminalization}

Immigration and criminalization are closely intertwined. Criminal law has played, and is increasingly playing, a potent role in how irregular migration and migrants are treated and perceived. The association of migration with crime and the proactive pursuit of that association is so deep and multifaceted that it has merited a distinct sub-discipline, "crimmigration." 22 Alongside the rhetoric of threat and criminality increasingly present in public discourse, ${ }^{23}$ the association of immigration and crime may be direct, through the criminalization of certain forms of migration. ${ }^{24}$

\footnotetext{
${ }^{22}$ See Juliet Stumpf, The Crimmigration Crisis: Immigrants, Crime, and Sovereign Power, 56(2) Am. U. L. REV. 367 (Dec. 2006); Ben Bowling \& Sophie Westenra, Crimmigration, in The Routledge Companion to Criminological TheORY AND ConCEPts 253 (Avi Brisman et al. eds., 2017); Crimmigration In Australia (Peter Billings ed., 2019); Cecilia Menjivar et al., The Expansion of "Crimmigration," Mass Detention, and Deportation, 12 Sociology ComPASs (2018); see also the work of the Crimmigration Clinic at Harvard Law School, https://hls.harvard.edu/dept/clinical/crimmigration-clinic/.

${ }^{23}$ Bastian A. Vollmer, Policy Discourses on Irregular Migration in the EU - "Number Games" and "Political Games," 13 EUR. J. Migration \& L. 317, 320 (2011).

${ }^{24}$ See, e.g., Section 35, of the United Kingdom Asylum and Immigration (Treatment of Claimants, etc.) Act 2004 (criminalizing lack of cooperation in the process of obtaining documents to facilitate deportation). See Cathryn Costello, Victim or Perpetrator? The Criminalised Migrant and the Idea of "Harm" in a Labour Market Context, in CRIMINALITY AT WORK (Alan Bogg et al. eds., forthcoming 2020). Ryszard I. Cholewinski, The Criminalisation of Migration in EU Law and Policy, in WHOSE Freedom, Security and Justice? EU Immigration And Asylum LaW and Policy (Anneliese Baldaccini et al., 2007); Elspeth Guild, Criminalisation of Migration in Europe: Human Rights Implications, (Council of Europe Issue Paper, 2009), http://cmr.jur.ru.nl/cmr/docs/criminalisation_en.pdf.
} 
More often, however, it will be indirect. The tool of criminalization may be directed at those perceived as facilitating, allowing, or supporting migration. In this sense, the fight against irregular migration is facilitated through the criminalization of the smugglers and the "disruption of their business model." An expanding regime of transnational criminal law obligates states to take a farreaching punitive approach, ${ }^{25}$ supported and militarized through Security Council resolutions. ${ }^{26}$ The expanding transnational criminal law regime against migrant smuggling is boosted through the focus placed on smugglers and its attendant criminalization, and is frequently expanded to include humanitarian organizations performing the role of search and rescue, which are accused of being corrupt or whose humanitarian acts are criminalized for performing or benefiting the role of smugglers. ${ }^{27}$

Finally, the criminalization of migrants occurs implicitly, and equally effectively, through their treatment like convicted criminals. Their detention in carceral conditions would make it very difficult to think otherwise. ${ }^{28}$ It is therefore understandable that the newly elected US President, when scrutinizing his Australian counterpart on the merits of a deal for the transfer of the Manus Island and Nauru detainees made by his predecessor, found it hard to see the difference: "I guarantee you they are bad. That is why they are in prison right now. They are not going to be wonderful people who go on to work for the local milk people." 29

The formation of, and lacunae within, international migration and refugee law may also be partly to blame here. Article 31 of the Refugee Convention calls for the non-prosecution for illegal entry or presence of refugees who are "coming directly from a territory where their life or freedom was threatened in the sense of article 1, enter or are present in their territory without authorization, provided they present themselves without delay to the authorities and show good cause for their illegal entry or presence," but it has been narrowly interpreted in some jurisdictions as a defense and has failed to significantly limit prosecutions. ${ }^{30}$ The struggle over the establishment of a clear-cut right to receive asylum ${ }^{31}$ and the absence of a right to enter beyond specific treaty provisions ${ }^{32}$ afford leeway and discretion in the assessment of claims that, while circumscribed by specific rules like non-refoulement, may allow security or even punitive considerations to

\footnotetext{
${ }^{25}$ Protocol against the Smuggling of Migrants by Land, Sea and Air, Dec. 12, 2000, 2241 U.N.T.S. 507.

${ }^{26}$ See S.C. Res. 2240, U.N. Doc. S/RES/2240 (Oct. 9, 2015), and S.C. Res. 2380, U.N. Doc. S/RES/2380 (Oct. 5, 2017).

${ }^{27}$ One such example is the case of Team Humanity, a Greek NGO. Since 2015, the NGO has provided assistance to the Hellenic Coast Guard in the rescue of asylum seekers crossing the Aegean from Turkey to Lesvos, participating in more than 150 missions. In January 2016, Team Humanity's director, Salam Aldeen, was prosecuted for the felony of illegal transport of irregular migrants, in its aggravated form, with the use of "rescue as pretext." He was eventually acquitted by the Court of Appeals. GLAN filed a case at the European Court of Human Rights on behalf of Salam Aldeen, against Greece, which was, however, summarily dismissed. See Case Filed against Greece in Strasbourg Court over Crackdown on Humanitarian Organisations (Apr. 18, 2019), https://www.glanlaw.org/single-post/2019/04/18/Case-filed-against-Greece-in-StrasbourgCourt-over-Crackdown-on-Humanitarian-Organisations. See also the Research Social Platform on Migration and Asylum, Crackdown on NGOs and Volunteers Helping Refugees and Other Migrants (2019), http://migpolgroup.com/wp-content/ uploads/2019/06/Final-Synthetic-Report-Crackdown-on-NGOs-and-volunteers-helping-refugees-and-other-migrants_1.pdf. See generally Eugenio Cusamano \& James Pattison, The Non-Governmental Provision of Search and Rescue in the Mediterranean and the Abdication of State Responsibility, 31 CAMBRIDGE REV. INT'L AfF. 53 (2018).

${ }^{28}$ For the requirement, under EU law, to separate detained asylum seekers and "ordinary prisoners" see art. 16(1) of Directive 2008/115. See also Joined Cases C-473/13 and C-514/13, Adala Bero v. Regierungspräsidium Kassel and Ettayebi Bouzalmate v. Kreisverwaltung Kleve (July 17, 2014), http://curia.europa.eu/juris/document/document.jsf? text $=\&$ docid $=155112$ \&pageIndex $=0 \&$ doclang $=\mathrm{EN} \&$ mode $=$ lst \&dir $=\& o c c=$ first $\&$ part $=1 \& \mathrm{cid}=6428262$.

${ }^{29}$ Greg Miller, Julie Vitkovskaya \& Reuben Fischer-Baum, “This Deal Will Make Me Look Terrible”: Full Transcripts of Trump's Calls with Mexico and Australia, The Washington Post (Aug. 3, 2017), https://www.washingtonpost.com/ graphics/2017/politics/australia-mexico-transcripts/. The reference to "the local milk people" remains unclear.

${ }^{30}$ Convention Relating to the Status of Refugees, July 28, 1951, 189 U.N.T.S. 137. See also Cathryn Costello, Yulia Ioffe \& Teresa Büchsel, Article 31 of the 1951 Convention relating to the Status of Refugees (UNHCR Legal and Protection Policy Research Series PPLA/2017/01, 2017).

${ }^{31}$ See Guy S. Godwin-Gill \& Jane McAdam, The Refugee in International Law ch. 7 (3rd ed. 2007); ItAmar ManN, Humanity at Sea: Maritime Migration and the Foundations of International LaW ch. 1 (2016).

${ }^{32}$ See Vincent Chetail, International Migration Law 119 (2019).
} 
dominate. The perceived strict distinction between those meriting refugee status because of a credible fear of persecution and the "rest" creates a sense that the latter are undeserving and dangerous chancers. The recognition of a sovereign right to detain asylum seekers and the absence of strict upper limits for the duration of the detention, even if subject to procedural and human rights limitations, similarly, and effectively, provides an avenue for punitive treatment. ${ }^{33}$

The close association of criminal law and migration therefore goes mostly one way: Irregular migrants are cast as the criminals endangering states, not as victims of state crimes. This is no surprise. Criminal law is long recognized as being primarily and predominantly in the service of power-at least that of the state. ${ }^{34}$ In this context, international law has not proven capable of overcoming domestic efforts to criminalize migration or to make migrants seem like prima facie criminals. Indeed, the interpretation of international law as an apology of the power of dominant (state) actors is, of course, a similarly well-established critique. ${ }^{35}$ These critiques become even more poignant when applied to ICL. The regime's relative youth, its rhetorical excess, and the selectivity of its application have provided ample material for the observation that it has primarily served as a tool against the weak. ${ }^{36}$ What is more, when it comes to the targets of investigations and prosecutions at the ICC, the Court's still predominant geographical focus can be perceived to associate international criminality with the poorer parts of the world, where immigrants come from. ${ }^{37}$ Finally, the exclusion from refugee status of individuals who have committed an international crime ${ }^{38}$ provides an ICL tool in the limitation of the provision of asylum and reinforces the predominant relationship between migration and criminalization. Migrants are therefore associated with criminality by virtue of their mere migration, directly or indirectly, in domestic, transnational and international criminal law.

Would it be possible to explore the reversal of this configuration of power and criminalization? Could the labeling power of (international) criminal law be deployed against the (powerful, receiving) state? Could it be marshaled against those that treat migrants like criminals? What would be the value of attempting to articulate a description and assessment of anti-migrant policies and the violence against migrants using the categories of ICL?

My primary interest here is expressivist. ${ }^{39}$ The labels of the criminal law, from the construction of its concepts to their application to specific acts, by specific actors, carry normative weight. The

\footnotetext{
${ }^{33}$ See the literature referred to in id. at 132 et seq and Cathryn Costello, Human Rights and the Elusive Universal Subject: Immigration Detention under International Human Rights and EU Law, 19(1) IND. J. Global Legal StU. 257 (2012).

${ }^{34}$ A key figure for this critical association is, of course, Michel Foucault and his DiscipLINE AND PUNISH (1977). For an account and a critique see David Garland, Punishment and Modern Society: A Study in Social Theory chs. 6 \& 7 (1990).

${ }^{35}$ The seminal text here is Martti Koskenniemi, From Apology to Utopia: The Structure of the International Legal Argument (2005).

${ }^{36}$ Immi Tallgren's question, in her early analysis of the Rome Conference, remains resonant: "Are we not just writing yet another chapter to the stale story of the Strong and the Weak in international law?" Immi Tallgren, We Did It? The Vertigo of Law and Everyday Life at the Diplomatic Conference on the Establishment of an International Criminal Court, 12 LEIDEN J. INT'L L. 683,695 (1999).

${ }^{37}$ See, e.g., Extraordinary Session of the Assembly of the African Union, Addis Ababa, Oct. 11-12, 2013, Decision no. 1: Decision on Africa's Relationship with the International Criminal Court (ICC), Ext/Assembly/AU/Dec.1. For a discussion of ICL from a Third World Approaches to International Law Perspective, see Makau Mutua, Never Again: Questioning the Yugoslav and Rwanda Tribunals, 11 Temple InT'L \& Comp. L.J. 167 (1997), and John Reynolds \& Sujith Xavier, “The Dark Corners of the World": TWAIL and International Criminal Justice, 14 J. INT'L CRIM. JUST. 959 (2016).

${ }^{38}$ Art. $1 \mathrm{~F}(\mathrm{a})$ of the 1951 Convention on the Status of Refugees, July 28, 1951, 189 U.N.T.S. 137 [hereinafter Refugee Convention]. See also art. 33(2) of the Refugee Convention (where the rule of non-refoulement "may not, however, be claimed by a refugee ... who, having been convicted by a final judgement of a particularly serious crime, constitutes a danger to the community of that country"). See Sandesh Sivakumaran, Exclusion from Refugee Status: The Purposes and Principles of the United Nations and Article $1 F(c)$ of the Refugee Convention, 26 I.J.R.L 350 (2014). See also Catherine Dauvergne, The Troublesome Intersections of Refugee Law and Criminal Law, in THE Borders of Punishment: Migration, Citizenship AND Social EXClusion 76 (Katja Franko Aas \& Mary Bosworth eds., 2013).

${ }^{39}$ For a classical starting point on criminal law's function of expressing "a formal and solemn pronouncement of the moral condemnation of the community” see H.L.A. Hart, The Aims of the Criminal Law, 23 L. \& CONTEMP. ProBS. 401, 404 (1958).
} 
law declares or creates a "punitive solidarity," 40 which, by identifying what and who is bad, contributes to the coherence of the members of a society. The ambition of ICL has been even greater, constructing such solidarity at a global level, and on the basis of purportedly universal values. Through and beyond retribution and deterrence, ICL powerfully evokes and unleashes an expressivist force. What is more, in both retrospective and prospective terms, the application of ICL can influence political judgement as to who is, and who is not, on the right side of history. ${ }^{41}$

While a valid critique of ICL has been developed-and I return to it in the last part of this Article - it is important to appreciate the implications of applying ICL to violence against migrants. This turn to ICL is part of a wider conceptual battle concerning the types of violence deemed the worst, and relatedly the baseline of protection for all humanity. It can express, in an international system of deep inequalities of power and resources, who is the perpetrator and who is the victim. Finally, the application of ICL requires us to appreciate the values that are being attacked, in this instance, the values associated with migration itself and the liberty to pursue a better life. It also engages the debate about the best use for ICL institutions.

To simplify, there are two ways to look at transnational migration and its protection. The first one is exclusively humanitarian, and only protects people fleeing persecution and threats to their life and limb, undertaking a perilous journey, and requesting asylum. The role of international law is one of minimal protection of what has been termed "bare life." ${ }^{2}$ It is apolitical, of elementary universality, and anchored in an understanding of humanity associated with survival and physical suffering. The second way of addressing the phenomenon of migration appreciates its structural features. In this view, migration is not only the avoidance of suffering and death, it is also the proactive pursuit of a better life; it is not an appeal to an apolitical guarantee of humanity, it is a phenomenon reflecting movements across and against structures of political and economic inequality - triggered by violence and danger, but ultimately due to that very inequality.

We can observe similar faultlines in the debates over international crimes. International criminal law is often perceived, with some justification, as eschewing larger questions of inequality or structural violence and elevating narrower and also more spectacular types of violence and suffering. ${ }^{43}$ Appreciating the social value of transnational migration in our analysis of the violence wielded against migrants can help us investigate whether ICL can go beyond the narrow violence against "bare life." 44

The traditional association between criminality and migration, one directed against migrants, and the predominant focus of ICL on physical violence committed in the poorer parts of the world, make it hard to associate violence against migrants with international crimes, and to see those conducting it as perpetrators of such crimes. In what follows, I want to explore how key categories of ICL can apply to policies involving violence against migrants, with the purpose of deterring migration flows, in order to challenge that assumption.

\footnotetext{
See also Saira Mohamed, Deviance, Aspiration, and the Stories We Tell: Reconciling Mass Atrocity and the Criminal Law, 124 YALE L.J. 1628 (2015), for ICL's "aspirational expressivism," and Barrie Sander, The Expressivist Turn of International Criminal Justice: A Field in Search of Meaning, 32(4) L.J.I.L. 851 (2019) for an excellent taxonomy of different types of expressivism and the characterization of GLAN's ICL work as "strategic expressivism."

${ }^{40}$ The starting point here has been the philosophy of Durkheim and his The Division of Labor IN Society. See Garland, supra note 34, at chs 2 \& 3. See also Henrique Carvalho \& Anastasia Chamberlen, Why Punishment Pleases: Punitive Feelings in a World of Hostile Solidarity, 20(2) Punishment \& Society 217 (2018).

${ }^{41}$ For a guide to the historical work of international criminal trials see Barrie Sander, History on Trial: Historical Narrative Pluralism within and beyond International Criminal Courts, 67 I.C.L.Q. 547 (2018).

${ }^{42}$ The concept is from Giorgio Agamben, Homo Sacer: Sovereign Power and Bare Life (1998). See Itamar Mann, Humanity at SeA Introduction (2016).

${ }^{43}$ Kalpouzos \& Mann, supra note 5.

${ }^{44}$ See also Itamar Mann, Crimes against Refugees as Crimes against Humanity (draft on file with the author) (discussing whether the limitation of the liberty of migration can serve the ossification of structures of inequality and whether this supports a turn to ICL in response).
} 


\section{The Conceptual Battlegrounds of Crimes against Humanity}

Crimes against humanity are defined in both customary international law and treaty, most notably article 7 of the Rome Statute of the ICC, as a series of prohibited acts, some of which will be discussed below, "committed as part of a widespread or systematic attack against any civilian population." ${ }^{25}$ The application of the category of crimes against humanity to violence against migrants entails engagement with key conceptual battles related to their definition and meaning. ${ }^{46}$ One can start with the prohibited acts, seen by the law as potentially constituting the overall attack, before turning to their breadth or systematicity (the so-called context element). ${ }^{47}$

\section{Murder}

The first such act is the most elusively simple one: "murder." The challenge here is whether we can understand murder in some way differently from a physically and somatically violent proximal act where the consequences of the perpetrator's actions in taking another person's life are manifest. Can the legal concept of murder accommodate the distance that current migration control practices employ? The Elements of Crimes facilitate this move by equating the act of killing, as part of the crime of murder, with "causing death," 48 whether by act or omission. The deaths of many migrants as a consequence of developed states' policies of migration deterrence occur not through direct acts of murder (such as the shooting of a migrant by a police officer) but often as a result of distancing practices. Such policies include the outsourcing of migration control through the establishment or support of detention centers in third states ${ }^{49}$ or the establishment of zones of danger through which migrants need to travel in peril..$^{50}$ At the very least, such measures significantly increase the risk of death. ${ }^{51}$ Such distance and such danger are established through proactive policies of empowering third states to intercept and to block migrants' journeys to claim asylum ${ }^{52}$ and through the ceasing or withholding of lifesaving operations to provide rescue in the migrant's immediate attempt to reach the territory where they can claim asylum. It is also established through push-backs to areas of danger. Crucially, states complement the proactive creation of that

\footnotetext{
${ }^{45}$ While specific prohibited acts are addressed in other treaty texts, unlike with the crime of genocide, there has not yet been a distinct treaty text on crimes against humanity. For the UN International Law Commission's work towards a potential codification see the Analytical Guide, https://legal.un.org/ilc/guide/7_7.shtml. And see FORGING A CONVENTION ON CRimes Against Humanity (Leila Nadya Sadat ed., 2011).

${ }^{46}$ For the evolution of law from the point of view of conceptual history, highlighting the "polemical" nature of legal concepts and the debates surrounding them, see Martti Koskenniemi, A History of International Law Histories, in THE OXFORD Handbook of the History of International Law 943, 968-69 (Bardo Fassbender \& Anne Peters eds., 2012).

${ }^{47}$ The ones discussed below are only a selection. In cases related to violence against migrants, other prohibited acts potentially constituting crimes against humanity may have been committed. For example, the Australia ICC submission, at 74-87, also details reasonable grounds to believe the crimes of torture (art. 7(1)(f) of the Rome Statute) and other inhumane acts (art. $7(1)(\mathrm{k})$ of the Rome Statute) were committed.

${ }^{48}$ ICC Elements of Crimes 7(1)(a)(1) and footnote 7. The Elements of Crime are an official, if not binding, aid to the Court's interpretation of its Statute.

${ }^{49}$ See, e.g., Sally Hayden, Deaths Pile up in Libyan Detention Centre, Leaked UN Report Shows, The IRISH TIMES (June 25, 2019).

${ }^{50}$ For the tracking of deaths in the Mediterranean see the International Organization of Migration monitoring, https:// missingmigrants.iom.int/region/mediterranean. See also Agnes Callamard, Report of the Special Rapporteur of the Human Rights Council on Extrajudicial, Summary or Arbitrary executions, U.N. Doc. A/72/335 (Aug. 15, 2017).

${ }^{51}$ To the extent that the perpetrators had knowledge that the consequence (of death) was likely, may have hoped it would not come about, but accepted its likely event in order to achieve their primary purpose (of curbing and deterring migration), we would be speaking not of dolus directus or indirectus but of dolus eventualis, a civil law concept of intent akin to, but slightly higher than, common law recklessness. The acceptability of dolus eventualis under art. 30, the default mental element of the Rome Statute, is the subject of debate. See, e.g., Mohamed E. Badar, The Mental Element in the Rome Statute of the International Criminal Court, 19 CRIM. L. FORUM 473 (2008).

${ }^{52} \mathrm{~A}$ recent example of such measures is the Greek Ministry of Defense's advertisement, on Jan. 24, 2020, for the procurement of floating barriers to block the passage of asylum seekers. The document can be found at http://army.gr/sites/default/ files/asdys_dpm_2.pdf.
} 
distance, which has predictable consequences, with the omission of acts that would avert such consequences.

Omission is equated with action when there is a legal duty to act. Doctrinally, therefore, part of the battle relates to the understanding of what constitutes a legally relevant omission and what the legal obligation to act is. The establishment of such a duty in law, and its territorial reach, will depend on a number of legal regimes, including positive duties under international human rights law. In some scenarios, the law of the sea and the specific regulation of search and rescue operations are pertinent. Establishing positive duties to act extraterritorially is difficult. Even if there is a specific or general duty to protect, ${ }^{53}$ this will not extend to a general obligation beyond the state's maritime zones, apart from instances where a flag vessel is in a position to de facto exercise the control that would allow it to protect the right to life.$^{54}$ A legal duty to act, however, can also be constituted through a prior act that has led to the creation of danger that certain consequences will occur. ${ }^{55}$

Therefore, there are two ways of conceptualizing the combination of action and omission and their role in the causing of death. The first is one based on omission, starting from the observation that states fail to avert death, and arguing for a legal duty, even if one cannot be established in extraterritorial search and rescue obligations, resulting from the states' prior endangerment of the migrants through their policies of making it harder and more dangerous for them to make the journey to claim asylum. The second calls for an integrated understanding of acts and omissions demonstrated in such policies. According to this approach the deaths are a direct consequence either of the distancing measures or of states' actions to stop rescue efforts. The latter could be observed in European states' decision to shift from Operation Mare Nostrum to Operation Triton, through which Italy in cooperation with the European Union stopped patrolling the sea outside its territorial waters in the knowledge that this would lead to the death of migrants. ${ }^{56}$ This analysis sees inaction as action, that is proactive withdrawal, with extra-territorial effects. As with the failure to act, the withdrawal of an action will be legally relevant if there is a duty to sustain it, either a positive legal duty or one based on the effects of prior action. Even if we accept the causal link between these policies and the deaths of migrants, at least as a conditio sine qua non with normative weight, we should appreciate that these arguments seem stretched and hard to make. This is because the default position of the law of murder, within the regimes of ICL and general international law, favors those who are able to maintain distance between their actions and their consequences.

\section{Imprisonment}

At the heart of anti-migrant policies is the practice of detention. Such detention occurs in the territory of Western states, in more or less lawful and humane ways, but it is also a component of the extra-territorial outsourcing of such policies. The detention of migrants in Libya, on behalf of the European Union, and in Manus Island and Nauru, on behalf of Australia, are important examples. The question for ICL is whether "unlawful imprisonment" 57 is limited to an

\footnotetext{
${ }^{53}$ See Irini Papanicolopulu, International Law and the Protection of People at Sea ch. 4 (2018).

${ }^{54}$ For the discussion of these questions in this Special Issue, see Nikolas Feith Tan \& Thomas Gammeltoft-Hansen, A Topographical Approach to Accountability for Human Rights Violations in Migration Control, in this issue; Itamar Mann, The Right to Perform Rescue at Sea: Jurisprudence and Drowning, in this issue; Efthymios Papastavridis, The European Convention of Human Rights and Migration at Sea: Reading the "Jurisdictional Threshold" of the Convention Under the Law of the Sea Paradigm, in this issue.

${ }^{55}$ See Michael Duttwiler, Liability for Omission in International Criminal Law, 6 INT'L CRIM. L. ReV. 1 (2006); MiLES JACKSON, COMPLICITY IN INTERNATIONAL LAW 107 (2015).

${ }^{56}$ See also Omer Shatz \& Juan Branco, Communication to the Office of the Prosecutor of the International Criminal Court Pursuant to Article 15 of the Rome Statute on EU Migration Policies in the Central Mediterranean and Libya (2014-2019), para. 604 et seq. (2019), https://www.statewatch.org/news/2019/jun/eu-icc-case-EU-Migration-Policies.pdf.

${ }^{57}$ Art. 7(1)(e) of the Rome Statute refers to "unlawful imprisonment or other severe deprivation of physical liberty in violation of fundamental rules of international law."
} 
irredeemably arbitrary process of physical incarceration by violent and illegitimate actors. We see such spectacular arbitrariness in armed conflicts that have provided the material for the existing jurisprudence of ICL on the question of detention and are associated with a sadistic and exceedingly violent treatment of detained human beings, as evidenced most spectacularly in jurisprudence ranging from the Second World $\mathrm{War}^{58}$ to the former Yugoslavia. ${ }^{59}$ The definition of unlawful imprisonment is doctrinally primarily dependent on its arbitrariness, ${ }^{60}$ with the inhumanity of its conditions playing a secondary, bolstering, role. ${ }^{61}$ Accordingly, both the nature of the actors, and their procedures, and the cruelty and inhumanity of their behavior, which may often include an element of sexual violence, ${ }^{62}$ make up the picture of the prohibited act.

While such behavior also occurs in migrant detention, ${ }^{63}$ the challenge is whether the interpretation of the prohibited act is able to capture the structure of indefinite detention organized by wellfunctioning and democratic states related to, and despite, the discretion international law grants to such states in the enforcement of their borders. There are a few difficulties to start with: Firstly, the very practice of detention for the purposes of processing is neither per se unlawful, nor is it criminal. ${ }^{64}$ Secondly, procedural guarantees, perhaps not unlike those associated with (temporary) deprivation of liberty more generally, are a matter of debate. ${ }^{65}$ Thirdly, the absence of absolute temporal limits for detention blurs the line between prolonged and indefinite. To the extent that the power to detain is linked with the sovereign's prerogative to control and process, and to the extent that it is not a form of violence that is as spectacular as direct physical harm, it is hard to place at the heart of the powerful ICL category of crimes against humanity (CAH). And yet, it is at the heart of a deep, farreaching and systemic exercise of violence on asylum seekers. ${ }^{66}$ It perceived as successful in part because of its very arbitrariness, the spear of the punitive function of anti-migrant violence.

The violence of detention attacks the very value that migrants are exercising, namely the freedom to move and, by moving, seek a better life. Physical liberty is at the heart of the phenomenon of migration, and values that the international normative system recognizes and protects. Therefore, the punitive - as well as arbitrary and inhumane-deprivation of that liberty is at the heart of the violence exercised against particular human beings as well as against the value

\footnotetext{
${ }^{58}$ Imprisonment was not included as a separate prohibited act in the Nuremberg and Tokyo statutes but was first included in the category through Allied Control Council Law No. 10, art. II para. 1 (c).

${ }^{59}$ See, e.g., Dario Kordić \& Mario Cerkez, Case No. IT-95-14/2-T, Trial Chamber (Int'l Crim. Trib. for the Former Yugoslavia Feb. 26, 2001), where the Trial Chamber found, para. 781-2 that the whole village of Rotilj within the Kiseljak municipality was turned into "a detention camp for Muslims from the other villages in the municipality, together with the surviving Muslims from Rotilj itself." See also Prosecutor v. Milorad Krnojelac, Case No. IT-97-25-T, Judgement, Trial Chamber (Int'l Crim. Trib. for the Former Yugoslavia Mar. 15, 2002) (addressing the violence in the infamous KP Dom detention camp in Foča).

${ }^{60}$ See Dario Kordić \& Mario Čerkez, Case No. IT-95-14/2-A, Appeals Chamber, para. 116 (Int'l Crim. Trib. for the Former Yugoslavia Dec. 17, 2004).

${ }^{61}$ See OtTo TrifFterer \& Kai Ambos, Rome Statute of the International Criminal CourT: A Commentary (2015), marginal note 51, with reference on further sources for the substantive human rights law of treatment of detainees. The OTP Response, in accepting that "multiple acts of imprisonment or severe deprivation of liberty" under art. 7(1)(e) were committed, and while noting the duration of the imprisonment, did not address its arbitrary nature, but focused on the conditions of the detention. This particular focus facilitated the OTP treating the detention as conditions that Australia "fail[ed] ... to take adequate measures to address" and not as Australia's "organizational policy" constituting crimes against humanity. This is further discussed below.

${ }^{62}$ This can be addressed through the act of sexual slavery in art. 7(1)(g). See Prosecutor v. Kunarac, Case No. IT-96-23-T, Trial Chamber (Int'l Crim. Trib. for the Former Yugoslavia Feb. 22, 2001) (on the "rape camps" in the former Yugoslavia).

${ }^{63}$ For sexual violence in detention in Australia see Philip Moss, Review into Recent Allegations Relating to Conditions and Circumstances at the Regional Processing Centre in Nauru 3-5 (Feb. 6, 2015) [hereinafter the Moss Report]; See also U.N. Support Mission in Libya \& Office of the High Commissioner for Human Rights, Desperate and Dangerous: Report on the Human Rights Situation of Migrants and Refugees in Libya, at 45-47 (Dec. 20, 2018), https://www.ohchr.org/Documents/Countries/LY/LibyaMigrationReport.pdf.

${ }^{64}$ Chetail, supra note 37 , at 134.

${ }^{65}$ See Human Rights Committee, General Comment No. 35 on Article 9 (Liberty and Security of the Person), U.N. Doc. CCPR/C/GC/35, para. 18 (Dec. 18, 2018) (on immigration detention).

${ }^{66}$ Boochani, supra note 1.
} 
of migration in general. The application of that particular category of CAH to detention practices challenges ICL to capture this. The ICC Australia Communication tried to do this, placing unlawful imprisonment at the center of the overall policy, and highlighting the carceral nature of the deprivation of liberty, the arbitrariness and unlawfulness of the process, and its indefinite character. ${ }^{67}$ This indefiniteness, as reflected in the quotes by Behrouz Boochani opening this article, is at the heart of both the arbitrary and inhumane nature of the policy of detention, reaching the particular depth of the violence against migrants seeking freedom and a better life.

\section{Deportation}

Related, in doctrinal, conceptual, political and practical terms, is the practice of deportation. As a crime, it is defined in the Rome Statute as the "forced displacement of the persons concerned by expulsion or other coercive acts from the area in which they are lawfully present, without grounds permitted under international law." The definition, while capturing the direct or indirect violence by de jure or de facto state agents, ${ }^{68}$ imports the regulatory framework of international refugee and migration law, and its attendant debates. How can the rules governing the prohibition of refoulement and collective expulsion, as well as the process of deportation of migrants, ${ }^{69}$ translate into the expressively powerful imaginary of ICL? Can this be applied to the well-organized policies of developed states and international organizations, from the $\mathrm{US}^{70}$ to Australia and the EU? Or does the procedural efficiency of a well-organized developed state, evoking at least a minimal understanding of the rule of law, preclude our understanding of the practice as criminal?

The crime of deportation requires the forcible displacement, within the territory of a state or across an international border, without permitted grounds under international law, of individuals who are lawfully present. The forcible nature of the displacement will be clear in cases where physical violence is used. However, the deportation of migrants may also include coercive circumstances, such as when detainees are "convinced" to agree to their removal as their only alternative to inhumane indefinite detention. ${ }^{71}$ The criterion of lawful presence poses more difficult questions. For the move to ICL, it is important to stress that such lawfulness is governed by international law, challenging the assumed prerogative of states in immigration matters. ${ }^{72}$

\footnotetext{
${ }^{67}$ ICC Australia Communication, at 63-73, including references to relevant findings by Human Rights bodies. See also Kalpouzos \& Mann, supra note 5, at 14-16 for the practice in Greece up to 2015. On the detention of migrants in Libya see the UNHCR Report cited supra 63. The latter example, given the spectacular nature of the violence and the perceived illegitimacy of many detaining actors and authorities doesn't pose many challenges for the application of ICL. The question there is its attribution to the cooperating European states, discussed below.

${ }^{68} \mathrm{See}$ ICC Australia Communication, at 87-92. The practice of illegal push-backs reported at the Evros border in NorthEastern Greece is the focus of a collaboration between GLAN and the Greek NGO HumanRights360. See HumanRights360, Ending Violent "Pushbacks" of Refugees and Migrants at the Greek-Turkish Border, https://www.humanrights360.org/newproject-ending-violent-pushbacks-of-refugees-and-migrants-at-the-greek-turkish-border/.

${ }^{69}$ See Michelle Hackman \& Alicia Caldwell, Immigration Tent Courts at Border Raise Due-Process Concerns, THE WALL STREET JOURNAL (Dec. 14, 2019), https://www.wsj.com/articles/immigration-tent-courts-at-border-raise-due-process-concerns-1157633 2002: "The unique conditions of [immigration] tent courts [at the border] deny migrants due process by depriving them of meaningful access to lawyers or interaction with judges, making the setup essentially a rubber stamp for deportation.”

${ }^{70}$ Jaya Rajmi-Nogales, Non-Refoulement under the Trump Administration, 23(11) ASIL INSIGHTS (2019), https://www.asil. org/insights/volume/23/issue/11/non-refoulement-under-trump-administration. It should be clarified that the amount of deportations has been high under previous US administrations as well. See Anthony W. Fontes, The Long, Bipartisan History of Dealing with Immigrants Harshly, The CHICAgo Reporter (Jul. 11, 2019), https://www.chicagoreporter.com/ the-long-bipartisan-history-of-dealing-with-immigrants-harshly/.

${ }^{71}$ Beyond physical coercion; for the coercion exercised on asylum seekers in the Australia immigration system see Ben Doherty, It's Simply Coercion: Manus Island, Immigration Policy, and the Men with No Future, The GuARDIAN (Sept. 28, 2016), https://www.theguardian.com/australia-news/2016/sep/29/its-simply-coercion-manus-island-immigration-policyand-the-men-with-no-future. On the insufficiency of "apparent consent" under threat see Prosecutor v. Simic, Tadic, and Zaric, Case No. IT-95-9-T, T.Ch. II, Judgement, para. 125 (Oct. 17, 2003).

${ }^{72}$ See Vincent Chetail, Is There Blood on my Hands? Deportation as a Crime in International Law, 29(3) LEIDEN J. INT'L L. 917, 925 (2016).
} 
However, the absence of a general right to entry limits the recourse to international law to the exception of refugees and asylum seekers, whose presence is lawful at least as long as their claim is pending. ${ }^{73}$ The grounds of expulsion are also governed by international human rights law and the principle of non-refoulement. ${ }^{74}$

Of course, not every unlawful removal of migrants engages ICL by constituting a crime against humanity. Qualitative and quantitative seriousness - the requisite gravity and the context of a widespread systematic attack-is required in order to transform a practice that is at the very heart of the modern sovereign state's control over its borders and territory from unlawful into criminal. Our application of the capacious expressive categories of ICL challenges us to see this practice as having travelled to the other edge of legality, that of international criminality, and not only across the line separating legal and illegal. Again, while it is perhaps easier to imagine deportations (or forcible internal transfers) in the inherently violent situation of armed conflict, linked with exterminatory practices and intent, ${ }^{75}$ some imaginative work is required in order to associate such criminal labeling with democratic states' policies in times of peace.

\section{Persecution}

Finally, similar challenges are posed by the application of the prohibited act of "persecution." The Rome Statute defines it as "the intentional and severe deprivation of fundamental rights contrary to international law by reason of the identity of the group or collectivity." 76 The general reference to fundamental rights, even as qualified by severity, arguably denotes this as the most complex and expansive subcategory of crimes against humanity. What is more, persecution reflects a strand distinct from the other prohibited acts, constituting its own "type" of crime against humanity as set out in the first articulation of the category in the Nuremberg Charter. ${ }^{77}$ In this sense, the crime of persecution refers to the fundamental failure, and intentional betrayal, of the obligations of governance towards a population under one's jurisdiction, reflected in the entire body of human rights law. Its application to migration therefore brings to ICL the difficult questions associated with the application of human rights law to the relationship between a state (or international organization) and migrant non-citizens. This may be in relation to acts that

\footnotetext{
${ }^{73} \mathrm{Id}$. at 926.

${ }^{74} I d$. at 926-29. ICC Australia Communication, at 90-1. In its Response to our Communication, however, the OTP seems to deny any link between the right to claim asylum and "lawful presence" under art. 7(1)(d). The OTP argued "that while the removal of migrants or asylum seekers to territories where they would be subjected to [cruel, inhuman and degrading treatment] would engage a State's human rights obligations, this does not affect the distinct legal question of whether the persons to be so removed were 'lawfully present' for the purpose of international criminal law and the crime of deportation. To consider otherwise would render the question of lawful presence under that provision relative to, or dependent on, the legality of a person's subsequent treatment. Such a circular approach would arguably be the opposite of the logic of the elements of the crime under article $7(1)(\mathrm{d})$, which seeks to ensure that only if persons are lawfully present are (sic) they protected from deportation or forcible transfer without grounds permitted under international law." The OTP does not provide a clear logic for what it considers necessary for "lawful presence" and by arguing, effectively, that "lawful presence" should mean that "only ... persons lawfully present" should be protected is, itself, circular. It should be added that the OTP seems to apply this analysis to asylum seekers "intercepted either in international waters or in Australia's territorial waters." OTP Response

${ }^{75}$ Here the example of Myanmar is important. For deportation as genocide see Chetail, supra note 72, at 933 et seq.

${ }^{76}$ Rome Statute art. 7(2)(g). See also Prosecutor v. Tadić, Case No. IT-94-1-T, Trial Chamber, Opinion and Judgement, para. 697 (Int'l Crim. Trib. for the Former Yugoslavia, May 7, 1997).

${ }^{77}$ Charter of the International Military Tribunal, Annex to the Agreement for the prosecution and punishment of the major war criminals of the European Axis, Aug. 8, 1945, 82 U.N.T.S. 279, 284 [hereinafter Nuremberg Charter]. Art. 6(c) of the Nuremberg Charter referred to crimes against humanity as: "murder, extermination, enslavement, deportation and other inhumane acts committed against any civilian population, before or during the war, or persecutions on political, racial or religious grounds in execution of or in connection with any crime within the jurisdiction of the Tribunal, whether or not in violation of the law of the country where perpetrated." This formulation has led to a separation between "murder-type" and "persecution-type" crimes against humanity. See United Nations WAR CRIMES Commission, History of THE UNITED NATIONS WAR CRIMES COMMISSION 192-94 (1948).
} 
constitute crimes under other provisions of crimes against humanity, ${ }^{78}$ or "behaviors that do not in themselves satisfy the listed definitions." 79

While potentially entailing physical violence, the crime of persecution is paradigmatically committed through the bureaucratic development of discriminatory policies, potentially capturing legislative and executive action far removed from those it affects. The discriminatory core of the crime of persecution highlights the difference in how irregular migrants, as opposed to people regularly present on the territory of a state, are being treated. ${ }^{80}$ Moreover, the substantive content of the crime of persecution, referring to fundamental rights that need to be protected, when applied to state policy, requires an acceptance that there is a relationship of governance and rights protection, even in relation to categories of people that the state would rather not be responsible for and admit on its territory. This relationship requires that the state does not intentionally violate their fundamental rights, in its territory and extra-territorially. Similarly to the other prohibited acts, the application of the crime of persecution to migration policy challenges us to understand the link between situations of systematic aggression where the state is "going after" a certain category of people with the situations where the state just wants nothing to do with them. In this way, it brings to the fore the claim at the very heart of the practice of migration, which is a claim to a humanity that is not just that of bare life, but also that of acceptance, inclusion and protection in (international) society.

\section{Part of an Overall Attack}

Prohibited acts, such as those described above, only constitute "crimes against humanity" if they are part of a "widespread or a systematic attack," which reflects a policy, ${ }^{81}$ "directed against any civilian population." The widespread or systematic nature of some of the acts described above depends on their integration and development within the states' migration policies. To the extent that some of these acts openly serve these policies, their systematic nature will be manifest. In terms of the definition of "attack," too, the doctrine is rather uncontroversially on the side of making this argument: It is clear that an "attack" does not require a "military attack," or require spectacular aggression appearing "out of the blue," but merely describes a "course of conduct," 82 which can be constituted by both physically violent and also purely administrative (at all levels of legislative, executive or judicial practice) acts or omissions. ${ }^{83}$ And yet, it remains intuitively difficult to

\footnotetext{
${ }^{78}$ The ICC Australia Communication, at 92-96, focused on persecutory acts of torture, unlawful imprisonment, deportation, and inhumane treatment.

${ }^{79}$ Prosecutor v. Tadić, Case No. IT-94-1-T, Trial Chamber, para. 703 et seq (Int'l Crim. Trib. for the Former Yugoslavia May 7, 1997).

${ }^{80} \mathrm{~A}$ case in point here is the particular policy of Australia in mistreating not migrants in general (although such mistreatment is also not absent) but specifically the ones arriving by boats. That was also part of what the Australian PM tried to explain to the US President in answering his question: "What is the thing with boats? Why do you discriminate against boats?" This has led some analysts to suggest that the operative category of discrimination is the "mode of arrival." See Claire Henderson, Australia's Treatment of Asylum Seekers: From Human Rights Violations to Crimes against Humanity, 12 J.I.C.J. 1180 (2014). In the ICC Australia Communication, at 94-95, it was argued that, on the contrary, the discrimination was against migrants in general, even if it was operationalized against those arriving by boat. The OTP Response found that the underlying acts potentially constituting persecution did "not appear to have been committed on persecutory grounds," without more.

${ }^{81}$ There has been debate over whether an actual "policy" is required and the level of organization necessary to conduct such a policy. In this instance, the fact that the Rome Statute refers to "a State or organizational policy" and the fact that the policies discussed are not those of precariously and barely organized non-state groups as some of the jurisprudence of the ICC, problematically, has allowed. See Prosecutor v. Germain Katanga Minority Opinion of Judge Christine Van den Wyngaert, Case No. ICC-01/04-01/07, Trial Chamber II, at 144 (Mar. 7, 2014). We will not need to discuss this further.

${ }^{82} \mathrm{See}$ ICC Elements of Crimes, Introduction to article 7. See also Prosecutor v. Bemba, Case No. ICC-01/05-01/08PTC II, para. 85 (June 15, 2009). On what the course of conduct may entail, see Prosecutor v. Gbagbo, Case No. ICC-02/11-01/11, Decision on the Confirmation of Charges against Laurent Gbagbo, para. 208-21 (June 12, 2014).

${ }^{83}$ For an examination of examples in the context of the overall concept see David Luban, A Theory of Crimes against Humanity, 29 YAle J. INT'L L. 85 (2004), who does, however, argue, at 101-2, that the attack requires something more "dynamic, ... moving, and ongoing" than "the erection of a stable system of group subordination or oppression."
} 
understand certain acts entailed in migration control policies as an "attack." that the state policies are a "response" to a pre-existing phenomenon, and one that is well within the rights, indeed the responsibilities, of a state. Therefore, if such a response contains elements of unlawfulness, even if these elements are widespread, there is too much space to traverse in order to characterize such actions as an overall "attack" constituting crimes against humanity.

The OTP Response to the ICC Australia Communication is exemplary of the traditional approach. The OTP could not find that Australia's "failure ... to take adequate measures to address the conditions of the detentions ... was deliberately aimed at encouraging an 'attack."' While conceding the role of deterrence at the heart of Australia's offshore detention policy, the OTP did not find that the unlawful aspects of the detention were "a deliberate, or purposefully designed, aspect of this policy." It also found that no other actor, including the corporations running the camps or the governments of Nauru or Papua New Guinea, had such a policy, thus rejecting the possibility of joint or accessorial liability. This analysis ignores the ample evidence that the conditions were deliberately created in order to serve such a deterrent purpose. ${ }^{85}$ Crucially, it sees both the arbitrary and inhumane nature of the detention not as the consequence of Australian government and corporate actions but as something that is created by itself, outside anyone's responsibility, ${ }^{86}$ and which Australian agents simply, and not deliberately, failed to assuage. ${ }^{87}$ The OTP position thus reinforces the traditional and continuous focus on "radical" or "spectacular" criminality. Western states may be guilty of "not doing enough in response," but the OTP's imaginary seems unable to understand this as an "attack."

Against such a stance, it is important to attempt to apply the lex lata to situations not naturally associated with it in order to both unlock the potential expressive range of the rules and expose increasingly normalized behavior to a revealing light. The doctrinal battles, whether over the prohibited acts or the contextual elements, are inscribed in a broader debate over the evolution, and definition, of the concept of crimes against humanity. What kind of phenomena, what kind of violence, what kind of relationships, what kind of perpetrators and victims does it seek to express? The initial establishment of the concept, as has been both historically and philosophically explained, ${ }^{88}$ captured a relationship of radical asymmetry of power, between a well-established and organized entity and a plurality of people who are vulnerable in relation to that power. That very asymmetry of power rested upon, and indicated, responsibilities of governance-or at least not their violent betrayal. The evolution of the concept of crimes against humanity, most notably through the gradual decrease of the required level of organization necessary to direct a policy, has allowed the application of the concept to increasingly disorganized non-state entities, ${ }^{89}$ from armed groups to terrorist organizations and potentially corporations, which, while functionally able to cause consequences to fall under the prohibited acts, have moved the concept away from its original design. In that sense a perceivably radical application of crimes against humanity

\footnotetext{
${ }^{84}$ I should say here that in the context of discussing, presenting, and debating the legal argument in relation to Australia, one of the major areas of push-back I experienced has been in understanding the policies as an "attack." Interestingly, such pushback has been less forthcoming from ICL scholars, for reasons explained in the next sentence of the text, and more from human rights and refugee law scholars, perhaps reflecting the broader perception of the technical term.

${ }^{85}$ See, e.g., ICC Australia Communication at 14-15.

${ }^{86}$ See also Heller, supra note 18.

${ }^{87}$ The requirement that the prohibited acts be "deliberately aimed at encouraging an 'attack"' seems to refer to footnote 6 in the ICC Elements of Crime. This states that "[a] policy which has a civilian population as the object of the attack would be implemented by State or organizational action. Such a policy may, in exceptional circumstances, be implemented by a deliberate failure to take action, which is consciously aimed at encouraging such attack. The existence of such a policy cannot be inferred solely from the absence of governmental or organizational action." (I thank Kevin Heller for suggesting this.)

${ }^{88}$ See Luban, supra note 83; Cherif M. BAssiouni, Crimes Against Humanity: Historical Evolution AND Contemporary Application ch. 1 (Legal Nature) (2011).

${ }^{89}$ Supra note 81 . For an account of the functional expansion of the criterion of organization, and criteria on its limits, see also Tilman Rodenhäuser, Beyond State Crimes: Non-State Entities and Crimes against Humanity, 27(4) LEIDEN J. INT'L L. 913 (2014).
} 
to violence against migrants may be seen as a return to the concept as originally imagined, while at the same time reflecting the modalities and responsibilities inherent in evolving global asymmetrical relationships of power.

Ultimately, the concept that the crime seeks to express carries a certain understanding of "humanity" itself, that most elusively capacious word. There is an important intersection between, on the one hand, the political and philosophical understanding of humanity in migration and, on the other hand, the role that the concept of humanity plays in the construction of the category of crimes against humanity in ICL. In both cases, there is a philosophical and political trajectory from the physical to the social. As introduced above, at the one end there is what has been called "bare life," 90 the very survival of the migrant, achieved through the rescue from persecution and the perilous journey. Accordingly, the violence most offensive to humanity, and ICL's priority, is the one that causes the most physical suffering and death. At the other end, we can appreciate migration as displaying humanity's transcendence of an apolitical "bare life," the overcoming of passive vulnerability, and a political claim made through the (perilous) exercise of physical liberty. Migration can even be conceived as a response to and against the global inequalities between North and South, a process of decolonization. ${ }^{91}$ This stance entails the appreciation of humanity as a social, relational concept. The attack against this value is not foreign to ICL, despite the fact that the predominant interpretation and practice of ICL has focused on the physical. Through an application and interpretation of crimes against humanity that, with reference to the social function of migration, emphasizes the structural features of ICL, we pose our understanding of what humanity needs to be defended. In this context, ICL can be used to highlight not only that migration is not a marginal, anomalous, innately wrong, or deviant practice-but also that it reflects a set of rich values inherent in humanity, which transcend the mere protection of life and also include the migrants' agency displayed in their liberty to move against the currents of global inequality.

\section{Outsourcing and Avoiding Responsibility}

\section{The Developing Practice of Distance}

The expressive power of (international) criminal law in labeling particular types of behavior and violence as criminal is only realized when such behavior is linked to individual moral actors. Conversely, the disposition to ignore or hide the gravity, in the broader sense, of the violence against migrants in structural arrangements is complemented by the avoidance of individual criminal responsibility for that violence. Both the wielding of the violence and the avoidance of responsibility are served by the establishment of distance. ${ }^{92}$ The desire of states to create such distance, from both migrants and the potential obligations associated with them, have led to an increasingly sophisticated set of practices the aim of which is to avoid, outsource, and distance responsibility, accountability, and liability. Such practices focus on the creation of distance in mainly two ways: physical distance, through extra-territorial "migration management" as far removed as possible; and moral and legal distance, through the employment of other state and non-state actors.

The example of Australia displays many of these features. The Australian punitive detention system very much focused on avoiding any contact between migrants and asylum territory, through interception at sea $^{93}$ and the establishment of the camps in the territory of Nauru

\footnotetext{
${ }^{90}$ See supra note 42 .

${ }^{91}$ Tendayi Achiume, Migration as Decolonization, 71 STAN. L. REv. 1509 (2019).

${ }^{92}$ The establishment of distance and the weakening of responsibility in the wielding of violence is also a central feature in the evolution of war. See Ioannis Kalpouzos, Double Elevation: Autonomous Weapons and the Search for an Irreducible International Law, LEIDEN J. INT'L L. (forthcoming 2020).

${ }^{93}$ See the analysis from the Andrew \& Renata Kaldor Centre for International Refugee Law, https://www.kaldorcentre.unsw. edu.au/publication/turning-back-boats-0. For an analysis of the Australian practice of "pushbacks" (including "takebacks" and
} 
and Manus Island, Papua New Guinea. These two states were also tasked, and financially motivated, to "own" the camps. ${ }^{94}$ Finally, reflecting the increasing privatization of "migration management," a series of corporations were contracted to run the camps. ${ }^{95}$

The EU model follows similar techniques in both major fronts. On the Eastern Mediterranean, the EU-Turkey agreement has entailed generous financial and geopolitical incentives in order to defer the management of a crucial migration route, stemming from the war in Syria, to the Turkish state. In the context of the North Africa migration route, the EU and specific states, most significantly Italy, have struck similar agreements with the government of Libya, ${ }^{96}$ but also with sub-state actors such as the Libyan Coast Guard, which are known to be engaging in trafficking, slavery, torture, and other human rights violations. ${ }^{97}$ Both alliances are central to the creation of distance and the avoidance of responsibility. To the extent that migrants overcome those barriers and reach the territory of an EU member state, a complex legislative and executive net places responsibility, to the extent possible, on relatively weaker EU border states. ${ }^{98}$

On the other side of the Atlantic, even though the current US administration seems happy to be openly associated with particular practices of arbitrary detention and inhumane treatment of migrant populations at the US/Mexico border, these practices have always been combined with efforts to outsource and avoid responsibility through agreements with Central and Southern American states. ${ }^{99}$

On all these fronts the states seem to either proactively or passively encourage the involvement of private or other non-state actors. The Australian model of the use of private security corporations is shared, perhaps unsurprisingly, by the US approach to its southern border. In order to

\footnotetext{
"turnbacks") see the report by the University of Goldsmith and Forensic Oceanography, in collaboration with GLAN, entitled "Unless the Water is Safer than the Lane" (Nov. 2017), https://www.gold.ac.uk/media/images-by-section/departments/ research-centres-and-units/research-centres/centre-for-research-architecture/Live-Project_CRA_2017.pdf.

${ }^{94}$ Before the Australian Parliamentary Select Committee on the Recent Allegations Relating to Conditions and Circumstances at the Regional Processing Centre in Nauru, the secretary of the Department of Immigration and Border Protection, Mr. Michael Pezzullo "reaffirmed the department's position: The Australian government does not run the Nauru Regional Processing Centre, or RPC. It is managed by the government of Nauru, under Nauruan law, with support from the Australian government. The government of Nauru operates the RPC, assesses asylum claims and, where persons are found to be in need of protection, arranges settlement. The government of Nauru is specifically responsible for security and good order and the care and welfare of persons residing in the centre." See Final Report: Taking Responsibility: Conditions and Circumstances at Australia's Regional Processing Centre in Nauru (Aug. 31, 2015), https://www.aph.gov.au/Parliamentary_ Business/Committees/Senate/Regional_processing_Nauru/Regional_processing_Nauru/Final\%20Report/c02.

${ }^{95}$ For the reports on the role of corporations see No Business in Abuse, Transfield's Complicity in Gross Human Rights Abuses within Australia's Offshore Detention Regime (Nov. 2015), https://d68ej2dhhub09.cloudfront.net/1321-NBIA_Report-20Nov 2015b.pdf; Amnesty International, Treasure Island: How Companies are Profiting from Australia's Abuse of Refugees on Nauru (Apr. 2017), https://www.amnestyusa.org/wp-content/uploads/2017/05/treasure_island_briefing_final5_0.pdf; for an analysis of the role and knowledge of corporate actors see ICC Australia Communication, at 56-58.

${ }^{96} \mathrm{See}$ Memorandum of Understanding on Cooperation in the Fields of Development, the Fight against Illegal Immigration, Human Trafficking and Fuel Smuggling and on Reinforcing the Security of Borders between the State of Libya and the Italian Republic (unofficial translation), https://eumigrationlawblog.eu/wpcontent/uploads/2017/10/MEMORANDUM_translation _finalversion.doc.pdf. See Hirsi Jamaa and Others v. Italy, App. No. 27765/09 (Feb. 23, 2012), http://hudoc.echr.coe.int/ eng? $\mathrm{i}=001-109231$.

${ }^{97}$ See EU Council, Note on Libya and the Surrounding Area: Current Situation and Need for Immediate Action (Sep. 4, 2019) (prepared for the High-Level Working Group on Asylum and Migration on Sept. 17, 2019), http://www.statewatch.org/ news/2019/sep/eu-council-libya-11538-19.pdf; Council of Europe Commissioner for Human Rights, Bridging the Protection Gap for Refugees and Migrants in the Mediterranean (May 2019), https://rm.coe.int/lives-saved-rights-protected-bridging-theprotection-gap-for-refugees-/168094eb87; see also leaked reports from Operation Sophia reported in Zach Campbell, Europe's Deadly Migration Strategy: Officials Knew EU Military Operation Made Mediterranean Crossing More Dangerous, PolITICO (Feb. 28, 2019), https:/www.politico.eu/article/europe-deadly-migration-strategy-leaked-documents/.

${ }^{98}$ See Minos Mouzourakis, "We Need to Talk about Dublin" Responsibility under the Dublin System as a Blockage to Asylum Burden-Sharing in the European Union (Oxford Refugee Studies Centre Working Paper Series No 105, Dec. 2015), https:// www.rsc.ox.ac.uk/files/files-1/wp105-we-need-to-talk-about-dublin.pdf.

${ }^{99}$ See for example the recent agreement between the US and Guatemala, supra note 22.
} 
maintain the impassability of the Mediterranean sea, the EU and its member states have not only empowered the Libyan Coast Guard, but have also used private actors, such as, for example, merchant vessels, in the practice of push-backs. ${ }^{100}$ Moreover, alongside states, migration or border management is also performed by EU specialized agencies, and specifically Frontex, ${ }^{101}$ the status and reviewability of which under EU administrative law is complex. ${ }^{102}$ Moreover, both at the EU external borders ${ }^{103}$ and along migration routes, ${ }^{104}$ local groups of vigilantes are allowed to operate. This latter phenomenon has also been documented in the southern border of the United States. ${ }^{105}$

While this panoply of actors reflects the complexity and extent of the mobilization of antimigration forces, it also reflects the increasing outsourcing of anti-migrant policies by the states of the Global North. To the extent that law, alongside political action, is an important avenue in identifying and addressing both direct and indirect state violence against migrants, international law offers a number of tools and regimes. Currently, the primary legal efforts within international law are based on questions of state responsibility and complicity, ${ }^{106}$ applying general public international law, human rights law, and refugee law. ${ }^{107}$ For these efforts, the main questions are whether the particular techniques of distancing, such as the arrangement between Italy and Libya or the use of private actors, can be addressed through the rules on state responsibility or the interpretation of Article 1 of the ECHR, establishing the applicability of the Convention. ${ }^{108}$

\footnotetext{
${ }^{100}$ See Forensic Architecture \& GLAN, Privatised Pushback of the Nivin (Dec. 18, 2019), https://forensic-architecture.org/ investigation/nivin. GLAN submitted a complaint against Italy before the UN Human Rights Committee. See Communication to the United Nations Human Rights Committee in the case of SDG against Italy (anonymized version) (Dec. 18, 2019), https://c5e65ece-003b-4d73-aa76-854664da4e33.filesusr.com/ugd/14ee1a_e0466b7845f941098730900ede1b51cb.pdf. For background, see https://www.glanlaw.org/nivincase.

${ }^{101}$ See Daniel Howden, Apostolis Fotiadis \& Anthony Lowenstein, Once Migrants on Mediterranean Were Saved by Naval Patrols. Now They Have to Watch as Drones Fly Over, The OBSERVer (Aug. 4, 2019), https://www.theguardian.com/world/ 2019/aug/04/drones-replace-patrol-ships-mediterranean-fears-more-migrant-deaths-eu.

${ }^{102}$ See generally Melanie Fink, Frontex and Human Rights: Responsibility in “Multi-Actor Situations” under the ECHR and EU Public Liability Law ch. 4 (2019); see also Melanie Fink, The Action for Damages as a Fundamental Rights Remedy: Holding Frontex Liable, in this issue.

${ }^{103}$ See Giorgos Christides, Steffen Lüdke \& Maximilian Popp, Videos Show Apparent Illegal Pushback of Migrants, DER SPIEGEL (Dec. 13, 2019), https://www.spiegel.de/international/globalsocieties/greece-videos-show-apparent-illegalpushback-of-migrants-a-1301228.html.

${ }^{104}$ On illegal push-backs and far-right vigilante groups operating in Central Europe and the Balkans see Border Violence Monitoring Network, Illegal Push-backs and Border Violence Reports, Balkan Region (Sep. 2019), https://www.borderviolence. eu/wp-content/uploads/September-2019-Report-1.pdf; Amnesty International, Pushed to the Edge Violence and Abuse against Refugees and Migrants along the Balkans Route (Mar. 2019), https://www.amnesty.org/download/Documents/ EUR0599642019ENGLISH.PDF.

${ }^{105}$ See Simon Romero, Militia in New Mexico Detains Asylum Seekers at Gunpoint, New York Times (Apr. 18, 2019), https://www.nytimes.com/2019/04/18/us/new-mexico-militia.html. In this instance the leader of that militia is being prosecuted. See Aimee Ortiz, Leader of Right-Wing Border Militia Pleads Guilty to Federal Gun Charge, New York TIMES (Jan. 3, 2020), https://www.nytimes.com/2020/01/03/us/militia-border-migrants-guilty.html.

${ }^{106}$ See U.N. Int'l L. Comm. (ILC), Articles on Responsibility of States for Internationally Wrongful Acts, UNGA A/56/10 and A/56/49(Vol.I)/Corr.4 (2001) [hereinafter ARSIWA]. "Aid or assistance in the commission of an internationally wrongful act: A State which aids or assists another State in the commission of an internationally wrongful act by the latter is internationally responsible for doing so if: (a) that State does so with knowledge of the circumstances of the internationally wrongful act; and (b) the act would be internationally wrongful if committed by that State." Id. art. 16.

${ }^{107}$ These are, of course, discussed elsewhere in this Special Issue; see, in particular, Itamar Mann, The Right to Perform Rescue at Sea: Jurisprudence and Drowning, in this issue; Violeta Moreno-Lax, The Architecture of Functional Jurisdiction: Unpacking Contactless Control-On Public Powers, S.S. and Others v. Italy, and the "Operational Model", in this issue.

${ }^{108}$ This is the focus point of the case S.S. and Others v. Italy, App. No. 21660/18, submitted by GLAN and the Association for Juridical Studies on Immigration (ASGI), on behalf of Seventeen survivors of a fatal incident in which a boat carrying migrants found itself in distress off the coast of Libya, with support from the Italian non-profit ARCI and Yale Law School's Lowenstein International Human Rights Clinic. The submission made use of evidence compiled by Forensic Oceanography, part of the Forensic Architecture agency based at Goldsmiths, University of London. See Moreno-Lax, supra note 107.
} 
While these legal regimes, and these interpretive techniques, offer significant tools to counter the avoidance of responsibility, they not only remain state-centric; there are also instances where reviewability is denied ${ }^{109}$ or where the rules of complicity or jurisdiction cannot travel back over the distance created. Indeed, a central element of distancing techniques is precisely to avoid legal responsibility, calibrating for example the level of support provided to external actors. From the point of view of navigating the existing structures and techniques of responsibility avoidance, is there an added value in turning to ICL? Assuming that some of the behavior is plausibly labeled an international crime, would there be an added value in employing ICL in order to individualize responsibility? Could ICL provide nimbler, more far-reaching, and more precise tools for identifying, expressing, and labelling the appropriate levels of responsibility in complex structures of policy and power?

\section{International Criminal Law's Promise in the Tracing of Responsibility}

One of the goals of the distance created and maintained by the practices of migration control is the depersonalization of the violence. Not only in the denial of the individual humanity of the migrants affected, but also in the obfuscation of the personal role and responsibilities of individual decisionmakers and actors. Through multiple layers of physical and administrative distance, key decision makers are disassociated from the potential consequences of their actions. This, alongside the perception of the violence against migrants as a normal consequence of their risky endeavors, or indeed their association with crime through direct or indirect criminalization, makes it difficult to think of key decision makers as criminally liable.

ICL's foundational ethos, whether expressed in the canonical prosecutorial call that international crimes are committed by "men, not abstract entities"110 or in influential philosophical insights in the "banality of evil," 111 promises to counter that distance and to humanize responsibility. Central in this task is the extraction of the individual's role and blame from collective action. From political and military leaders to foot soldiers, the image of the perpetrator of international crimes has been playing an evolving role in locating and humanizing the blame for complex and spectacular violence and suffering. ${ }^{112}$ At the same time, and despite the stated ambition to resolutely individualize blame, both the doctrine and the practice of ICL manifestly maintain the centrality of collective structures and therefore subject collectivities, including states, to the expressive effects of labelling. ${ }^{113}$ This can be seen in the definition of all core crimes: most clearly the crime of aggression, requiring a prior act of state; ${ }^{114}$ but also genocide, where, with the exception of the lone génocidaire cas d'école, a

\footnotetext{
${ }^{109}$ See European Council Press Release 144/16, EU-Turkey Statement (Mar. 18, 2016), available at https://www.consilium. europa.eu/en/press/press-releases/2016/03/18/eu-turkey-statement/. And see Cases T-192/16, T-193/16 and T-257/16 NF, NG and NM v. European Council (Feb. 28, 2017), declaring that the General Court lacks jurisdiction to review the "alleged agreement" and that, as per para. 72, "even supposing that an international agreement could have been informally concluded during the meeting of 18 March 2016, something which has been denied by the European Council, the Council of the European Union and the European Commission in the present cases, that agreement would have been an agreement concluded by the Heads of State or Government of the Member States of the EU and the Turkish Prime Minister."

${ }^{110}$ Robert H. Jackson, Opening Statement Before the International Military Tribunal, (Nov. 21, 2945), https://www. roberthjackson.org/speech-and-writing/opening-statement-before-the-international-military-tribunal/. See Gerry Simpson, Men and Abstract Entities: Individual Responsibility and Collective Guilt in International Criminal Law, in SYSTEM CRIMINALITY IN INTERNATIONAL LAW 69 (André Nollkaemper \& Harmen van der Wilt eds., 2009).

${ }^{111}$ Hannah Arendt, Eichmann in Jerusalem (1963); David Luban, Hannah Arendt as a Theorist of International Criminal Law, 11 INT'L CRIM. L. Rev. 621 (2011); Kalpouzos \& Mann, supra note 5.

${ }^{112}$ See Sofia Stolk, A Sophisticated Beast? On the Construction of an "Ideal" Perpetrator in the Opening Statements of International Criminal Trials, 29(3) EUR. J. INT'L L. 677 (2018).

${ }^{113}$ Frédéric Mégret, What Sort of Global Justice Is International Criminal Justice, 13(1) J. INT'L CRIM. JUST. 77 (2015).

${ }^{114}$ See Rome Statute art. 8bis.
} 
genocidal or systematically violent policy is crucial; ${ }^{115}$ crimes against humanity, where, the potential of widespread effects of isolated individual action to one side, the requirements of systematicity and a policy require collective structures; ${ }^{116}$ and even war crimes, at least through the inter-collective nature of the necessary contextual element of the existence of an armed conflict. ${ }^{117}$ The involvement of the collective also plays a significant role in the rules governing the operation of ICL. For example, the criterion of gravity, which determines the admissibility and prioritization of situations and crimes before the ICC, has been interpreted by the Prosecutor to include the systematicity of the crimes and the involvement of upper level authorities and state structures. ${ }^{118}$ Inevitably, prosecutorial selection is perceived as the association of the collectivity which the individual perpetrators represented in their impugned actions with the crimes themselves. ${ }^{19}$

The combination of ambitious individualization of blame with the recognition of the collective action through which, and maybe for which, the individual acted, is also very much reflected in the construction of modes of liability. That combination may be important in addressing violence against migrants. Doctrinal techniques, if convincingly constructed and employed, may be both consequential and revelatory in presenting to key institutions and to the public a case for blameworthiness of individuals far removed from the consequences of anti-migrant violence. At the same time, the collective labeling triggered by the employment of ICL categories and institutions could powerfully suggest the collective and shared responsibility of those of us who are citizens of the states wielding that violence.

More specifically, the ICL doctrines of modes of liability could potentially describe and address both vertical and horizontal structures. Vertical structures of authority are, for example, explored through concepts of command and superior responsibility in both military and civilian settings. ${ }^{120}$ These doctrines could potentially be applied to state or corporate structures of migrant detention. In this sense, the relations between Australian officials and officials in Nauru and Manus Island, or between corporate officers and employees in these very facilities, to the extent that they display the necessary levels of effective control, knowledge and intention, can be used to identify far removed perpetrators. ${ }^{121}$ In both cases, but especially in relation to the involvement of for-profit private and corporate actors, the application of the doctrine may allow the revelation that it is the very efficiency of the "business model" of migration management that constitutes the criminal liability of those in control.

\footnotetext{
${ }^{115}$ The debates around the specific role of an overall genocidal policy and its influence on the finding of individual liability include questions of evidentiary inference and questions of the definition of genocidal intent. See, e.g., Hans Vest, A StructureBased Concept of Genocidal Intent, 5 J. INT'L CRIM. JUsT. 781 (2007).

${ }^{116}$ On the requirement for a policy see, for example, Claus Kreß, On the Outer Limits of Crimes against Humanity: The Concept of Organization within the Policy Requirement: Some Reflections on the March 2010 ICC Kenya Decision, 23 LEIDEN J. INT'L L. 855 (2010). See also the debate supra note 81 on the Katanga case.

${ }^{117}$ Moreover, the development of case law has increasingly linked the finding of the necessary organization for a non-state armed group to qualify as a party to an armed conflict with the analysis of the same organization for the purposes of establishing individual liability. See Procureur v. Mathieu Ngudjolo Chui, Case No. ICC-01/04-02/12, jugement rendu en application de l'article 74 du Statut (Dec. 18, 2012), par. 339 et seq.

${ }^{118}$ International Criminal Court, Office of the Prosecutor, Policy Paper on Case Selection and Prioritisation (Sep. 15, 2016), https://www.icc-cpi.int/itemsDocuments/20160915_OTP-Policy_Case-Selection_Eng.pdf.

${ }^{119}$ See Marko Milanovic, Establishing the Facts about Mass Atrocities: Accounting for the Failure of the ICTY to Persuade Target Audiences, 47(4) GEO. J. INT'L L. 1321-1378 (2016).

${ }^{120}$ Art. 28 of the Rome Statute provides, with respect to civilian superiors that "a superior shall be criminally responsible for crimes within the jurisdiction of the Court committed by subordinates under his or her effective authority and control, as a result of his or her failure to exercise control properly over such subordinates, where: (a) The superior either knew, or consciously disregarded information which clearly indicated, that the subordinates were committing or about to commit such crimes; (b) The crimes concerned activities that were within the effective responsibility and control of the superior; and (c) The superior failed to take all necessary and reasonable measures within his or her power to prevent or repress their commission or to submit the matter to the competent authorities for investigation and prosecution."

${ }^{121}$ See ICC Australia Communication, 101-06.
} 
Similarly, combinations of vertical and parallel structures of action are addressed through the modes such as co-perpetration, ${ }^{122}$ and different levels of accessorial liability, including aiding and abetting, instigation, or any other contributions made with the necessary knowledge and the intent to further "the criminal activity or the criminal purpose of the group." ${ }^{123}$ While degrees of intentionality and knowledge vary, and specific instruments or jurisprudential lines of argument have been more restrictive, ${ }^{124}$ the modes' capacity to capture different types of collective behavior is quite expansive. ${ }^{125}$ The expressive value of articulating horizontal or combinations of vertical and horizontal structures may be to foreground the role of intentionality and knowledge in the formation of migration management and accountability avoidance strategies. Finally, in order to use the modes of liability as tools to address the actors' distance in violence against migrants, it will be important to consider that the conduct required for a particular type of liability may be a combination of actions and omissions.

For example, a public-private partnership like the one struck between the Australian government and private corporations including G4S, Wilson Security and Ferrovial could be explored through the mode of co-perpetration: Did both public and private parties make "essential contributions" in the execution of a common plan? ${ }^{126}$ Were these contributions aimed at the realization of those parts of the migration management strategy that can be understood as constituting international crimes? In the European context, can the relations between Frontex and specific states establish a relation of co-perpetration or accessorial liability of Frontex agents in the management of unlawful detention ${ }^{127}$ or unlawful deportations? ${ }^{128}$ Importantly, would the financial aid and material support ${ }^{129}$ provided by the European Union and its member states to actors, including the Libyan Coast Guard, involved in the process of pull-backs, detention, and inhumane treatment of asylum seekers satisfy the requirements of accessorial liability in the Rome Statute and/or customary ICL ${ }^{130}$

Not all of these questions need to be answered in the affirmative and an ICL analysis that assumes they should would fail to genuinely enquire how the modes in the doctrine map onto the world and would very quickly spend the expressivist capital of the doctrine. Instead, our

\footnotetext{
${ }^{122}$ Art. 25 of the Rome Statute provides that " $3 \ldots$ a person shall be criminally responsible and liable for punishment for a crime within the jurisdiction of the Court if that person: (a) Commits such a crime, whether as an individual, jointly with another or through another person, regardless of whether that other person is criminally responsible."

${ }^{123}$ Art. 25(3)(d) of the Rome Statute provides for liability for a person who "(d) In any other way contributes to the commission or attempted commission of such a crime by a group of persons acting with a common purpose. Such contribution shall be intentional and shall either: (i) Be made with the aim of furthering the criminal activity or criminal purpose of the group, where such activity or purpose involves the commission of a crime within the jurisdiction of the Court; or (ii) Be made in the knowledge of the intention of the group to commit the crime."

${ }^{124}$ On the debate over a "specific direction" criterion in the jurisprudence of the ICTY, see Prosecutor v. Perišić, Case No. IT-04-81-A, Judgment, para. 36 (Int'l Crim. Trib. for the Former Yugoslavia Feb. 28, 2013) [hereinafter Perišić Appeal Judgment]. For a critique, see Antonio Coco \& Tom Gal, Losing Direction: The ICTY Appeals Chamber's Controversial Approach to Aiding and Abetting in Perišić, 12 J. INT'L CRIM. JUST. 345 (2014). While that controversy has been settled towards a broader standard, the words "for the purposes of" in art. 25(3)(c) of the Rome Statute suggest that lawful types of assistance may be excluded. For the application of the standard in ICC jurisprudence, see Prosecutor v. Mbarushimana, Case No. ICC01/04-01/10, Decision on the Confirmation of Charges, para. 279 (Dec. 16, 2011), https://www.icc-cpi.int/pages/record.aspx? uri $=1286409$.

${ }^{125}$ See, e.g., Allison M. Danner \& Jennifer S. Martinez, Guilty Associations: Joint Criminal Enterprise, Command Responsibility and the Development of International Criminal Law, 9 CAL. L. REV. 150 (2005).

${ }^{126} \mathrm{See}$ on "the division of essential tasks for the purpose of committing a crime," Prosecutor v. Lubanga, Case No. ICC-01/ 04-01/06, Decision on the Confirmation of Charges, para. 342 (Feb. 7, 2007), https://www.icc-cpi.int/pages/record.aspx? uri $=266175$.

${ }^{127}$ Kalpouzos \& Mann, supra note 5, at 21-24.

${ }^{128}$ See Christides, Lüdke \& Popp, supra note 103.

${ }^{129} \mathrm{On}$ the extent and function of the European Union funding for Libyan migration control see report by Oxfam, The EU Trust Fund for Africa: Trapped between Aid Policy and Migration Politics (Jan. 30, 2020), https://policy-practice.oxfam.org.uk/ publications/the-eu-trust-fund-for-africa-trapped-between-aid-policy-and-migration-politics-620936.

${ }^{130}$ This, alongside other forms of liability, has been argued in Shatz \& Branco, supra note 56, paras. 972-1000.
} 
analysis of different actors' roles in the types of violence against migrants that constitute international crimes should aim to identify their material contributions and mental states. For example, one would have to determine whether an individual occupying a position in the corporate structure of company, through their executive decisions, provided an "essential contribution" to the act of unlawful imprisonment, while possessing, thanks to the existing corporate reporting structure, the requisite knowledge. ${ }^{131}$

As in the employment of the category of crimes against humanity to describe the exercise of democratic states' sovereign prerogatives, it can be revelatory to consider presumptively legitimate- or at least not criminal—structures of behavior from the point of view of ICL. It suggests that it is not inconceivable that actors who appear geographically, physically, but also rhetorically and aesthetically removed from the violence perpetrated against migrants could and should be associated with, and blamed for, that very violence.

As mentioned, ICL has long grappled with the question of remote actors with no physical blood on their hands, acting in unexceptional, conformist, "banal" ways. The case of Adolf Eichmann has served as a paradigm of this type of actor. ${ }^{132}$ This paradigm is both revelatory and obfuscatory. It is revelatory in reminding us of the moral and potentially legal liability of non-immediately violent actors, hidden behind a complex bureaucratic structure. Yet, that function of the paradigm-or, indeed, the parable is buttressed, supported, but potentially defanged through the all-encompassing spectacle of the evil of the Third Reich. It is therefore more difficult, even when the use of the doctrinal tools allows it, to imagine, trace, and appreciate individual responsibility in complex structures when the labeling of the very violence itself is a matter of debate. ${ }^{133}$ When even the border guards or coast guard actors don't seem to be perpetrating acts that qualify as international crimes, the distance of bureaucratic actors "responding" to a complex situation, an "emergency," allows for their placement outside the conceivable gallery of perpetrators. In this way, the application of the ICL concepts of crimes and individual responsibility invites us to challenge our understanding of the nature of violence against migrants itself, as well as the expanding system of responsibility avoidance that supports it.

\section{Engaging Global Institutions}

The expressive power of ICL is rooted in its definitions of criminality and its formulations of responsibility, but is pursued through its institutions. From the mobilization of prosecutorial prerogative through the performance of the trial ${ }^{134}$ to the imposition of punishment, ${ }^{135}$ both national and international courts claim the authority to apply the heavy concepts of ICL. Indeed, the evocation of these concepts empowers national courts to act, even when a close connection to the crime doesn't exist and to the extent that the state has instituted some form of universal jurisdiction. ${ }^{136}$ However, beyond the power of their characterization as international crimes, the transnational nature and potential global impact of crimes against migrants have

\footnotetext{
${ }^{131}$ It should be noted that both academic and advocacy applications of ICL in such instances usually, if not always, stop short of identifying, and making the case against, particular individuals. Instead, they request the relevant prosecutorial and investigative body to do so. This was the case with the ICC Australia Communication.

${ }^{132}$ For the point that Eichmann constitutes a "thought-experiment" irrespective from whether Arendt's description of the historical Eichmann is accurate, see Itamar Mann, Eichmann's Mistake - The Problem of Thoughtlessness in International Criminal Law, 33 CA. J. L. JURIS. 145 (2020).

${ }^{133}$ See also id.

${ }^{134}$ See Gerry SimpSON, LAW, WAR, AND CRIME ch. 5 (2007).

${ }^{135}$ Indeed, the expressivist, or communicative, theory of domestic criminal law has centered on the practice of punishment. See, e.g., Antony R. Duff, Punishment, Communication and Community (2001). This is only partially true in relation to the debate on the expressive function of international criminal law.

${ }^{136}$ On the selective application of universal jurisdiction see Frédéric Mégret, The "Elephant in the Room" in Debates about Universal Jurisdiction: Diasporas, Duties of Hospitality, and the Constitution of the Political, 6(1) TRANSNAT'L LEG. THEORY 89 (2015).
} 
particular consequences for the engagement of both national and international judicial institutions. The first concerns the transnational nature of the phenomenon of migration and how this is reflected in the finding of a court's jurisdiction. The second concerns the perceived importance of violence against migrants, and how this can be approached through the category of gravity, as a criterion for admissibility at the ICC. This section will discuss these in turn, before concluding with some thoughts on the engagement of international judicial institutions, and specifically the ICC.

\section{The Transnational Nature of Crimes Against Migrants and the Activation of Jurisdiction}

In September 2018 and in November 2019 a Pre-Trial Chamber (PTC) of the ICC authorized the Prosecutor to proceed with the investigation of alleged crimes committed in the situation in Myanmar against Rohingya civilians, targeted and forced to flee by the state and associated militias. ${ }^{137}$ The decisions are of importance for a number of reasons, not least in that they open the way for the Court to address a situation of widespread violence against individuals portrayed by the state as foreign bodies in need of expulsion. Indeed, while the Rohingya have inhabited the Rakhine province for generations, the rhetoric for their dehumanization is familiar: The Rohingya are characterized as "illegal immigrants" and as "criminals," with aggravating qualifications of a sexual ("rapists") and religio-political nature ("terrorists"). ${ }^{138}$ What is more, the violence against the Rohingya has paired exterminatory practices with the widespread phenomenon of forced displacement. At the heart of this is the act of forced, and unlawful, deportation. Indeed, the other main crime against humanity alleged and discussed in the decisions, persecution, is discussed as leading to deportation. ${ }^{139}$ We discussed these above; here it is important to focus on the context of jurisdiction. Indeed, part of the innovative importance of the ICC PTC's decisions is that they establish jurisdiction based on the transnational nature of the crimes.

The ICC has jurisdiction over crimes committed by nationals or on the territory of a state that has signed and ratified the Rome Statute. ${ }^{140}$ Myanmar has not, but its neighbor Bangladesh has. ${ }^{141}$ The Prosecutor submitted, and the PTC accepted, that to the extent that the crime of deportation entails the essential element of crossing a border, ${ }^{142}$ jurisdiction can be established even if just one, and not necessarily the initial, element of the crime occurs in the territory of a member state. The forceful and unlawful deportation of individuals from the territory of a non-member state to the territory of a member state falls within the jurisdiction of the Court. The second PTC decision went further. By equating a crime's "conduct" 143 with "actus reus" and by including the consequences of the crime within this concept, it accepts the potential transnational extension of

\footnotetext{
${ }^{137}$ Decision on the Prosecution's Request for a Ruling on Jurisdiction under Article 19(3) of the Statute, Case No. ICCRoC46(3)-01/18, Pre-Trial Chamber III (Sept. 6, 2018); Decision Pursuant to Article 15 of the Rome Statute on the Authorisation of an Investigation into the Situation in the People's Republic of Bangladesh/Republic of the Union of Myanmar, Case No. ICC-01/19-27, Pre-Trial Chamber III (Nov. 14, 2019). As the present article is going in print, the same situation, subject to different rules of jurisdiction, is before the International Court of Justice as a contentious case between the Gambia and Myanmar. See Application of the Convention on the Prevention and Punishment of the Crime of Genocide (The Gambia v. Myanmar), with documents available at https://www.icj-cij.org/en/case/178.

${ }^{138}$ See Human Rights Council, Detailed Findings of the Independent International Fact-Finding Mission on Myanmar, U.N Doc. A/HRC/42/CRP.5 (Sept. 16, 2019). See also Application of the Convention on the Prevention and Punishment of the Crime of Genocide (The Gambia v. Myanmar), Public sitting held on Tuesday Dec. 10, 2019, at 10 a.m., Verbatim Record, at 29-30 (for the terms used in genocidal language), https:/www.icj-cij.org/files/case-related/178/178-20191210-ORA-01-00-BI. pdf.

${ }^{139}$ ICC PTC, Decision on Authorisation, supra note 137, para. 109.

${ }^{140}$ See Rome Statute art. 12.

${ }^{141}$ Bangladesh deposited its instrument of ratification of the Rome Statute on Mar. 23, 2010. See https://asp.icc-cpi.int/ en_menus/asp/states\%20parties/asian\%20states/Pages/bangladesh.aspx.

${ }^{142}$ This should be distinguished from internal forcible transfer.

${ }^{143}$ Article 12(2)(a) of the Rome Statute refers to "The State on the territory of which the conduct in question occurred."
} 
jurisdiction even when the part of the conduct that occurs in the territory of a member state is not, as was the case with the crime of deportation, a legal element of the crime. ${ }^{144}$ This approach has been subject to critique, on grounds of clarity and treaty interpretation, ${ }^{145}$ presumption of state consent to the exercise of jurisdiction by an international court, or the pragmatic consequences in relation to the ability of the Court to investigate acts of non-cooperative states. ${ }^{146}$ But the examples reflect an instance where the transnational human movement empowers an international institution to assert jurisdiction. ${ }^{147}$

\section{Why Should the ICC Prioritize the Investigation of Crimes Against Migrants?}

If the transnational nature of the phenomenon facilitates the activation of multiple jurisdictions, then the widespread effects of violence against migrants may also be an important factor in the exercise and prioritization of such jurisdiction. The legal regime of the ICC provides certain criteria of admissibility, most importantly the concepts of complementarity and gravity, which determine whether it can exercise its jurisdiction. The criterion of gravity, discussed here, will also be an important factor in the decision of the Prosecutor to prioritize the investigation of certain situations and cases. ${ }^{148}$ As with the concepts and definitions of substantive crimes and modes of liability, the nature of the violence against migrants and the techniques of distancing invite us to re-think the rules on the exercise and prioritization of jurisdiction and, through this, the developing role of the ICC.

Left entirely undefined in the Rome Statute, and only gradually developed through the practice and statements of the OTP and the Court's Chambers, gravity is where the labeling power of ICL is put into effect and enhanced through the mobilization of the regime's central institution. While considerations of gravity lato sensu play a role in the qualification of an act as an international crime ${ }^{149}$ the additional application of gravity as a criterion of admissibility aims to legitimate the Court's (and Prosecutor's) action. The evolution and application of the criteria of gravity, accordingly, tell the story of what types of behavior, and what (collective) actors in different parts of the world, the Prosecutor and Court chooses to target.

Initially focused on rather crude quantitative criteria, ${ }^{150}$ a taxonomy of qualitative considerations has been gradually considered. The Court has increasingly recognized the abhorrence of particular types of violence, such as torture or sexual violence, the vulnerability of certain victims, such as children, and the systematic nature of their perpetration, including the involvement of high-level authorities. Beyond the capacity of certain types of violence and perpetration to "shock the conscience," 151 an increasingly dynamic understanding of the qualitative nature of gravity has

\footnotetext{
${ }^{144}$ See Decision Pursuant to Article 15 of the Rome Statute on the Authorisation of an Investigation into the Situation in the People's Republic of Bangladesh/Republic of the Union of Myanmar, Case No. ICC-01/19-27, Pre-Trial Chamber III, paras. 46-62 (Nov. 14, 2019).

${ }^{145}$ Dov Jacobs, ICC PTC Authorises Investigation in Bangladesh/Myanmar: Some Thoughts, SPREADING THE JAM (Nov. 15 , 2019), https://dovjacobs.com/2019/11/15/icc-ptc-authorises-investigation-in-bangladesh-myanmar-some-thoughts/.

${ }^{146}$ Douglas Guilfoyle, The ICC Pre-Trial Chamber Decision on Jurisdiction over the Situation in Myanmar, 73 AUSTRALIAN JOURNAL OF INTERNATIONAL AFFAIRs 2 (2019).

${ }^{147}$ Indeed, the same could apply to a domestic court's interpretation and application of the crime of deportation, to the extent that the unlawful deportation was to the territory of the state.

${ }^{148}$ See Rome Statute arts. 17 and 53.

${ }^{149}$ See, e.g., Rome Statute art. 7(1)(g) on sexual violence. See also the reference to a "similar character" of "other inhumane acts" for them to constitute crimes against humanity in art. $7(1)(\mathrm{k})$. Similarly, a notion of gravity plays a role for "serious" violations of international humanitarian law, constituting war crimes in customary law and the Rome Statute, e.g., in art. $8(2)(b)$.

${ }^{150}$ See ICC Office of the Prosecutor, Communication Concerning the Situation in Iraq, at 8 (Feb. 9, 2006). See Kevin Jon Heller, Situational Gravity Under the Rome Statute, in Future Perspectives in International Criminal Justice 230 (Carsten Stahn \& Larissa van den Herik eds., 2010).

${ }^{151}$ See the Preamble to the Rome Statute: "Mindful that during this century millions of children, women and men have been victims of unimaginable atrocities that deeply shock the conscience of humanity ...."
} 
been included in the OTP's considerations, through the term "impact." The OTP has accordingly summarized the criteria as "relating to the scale, nature, manner of commission, and impact of the crimes." 152

Some situations of systematic anti-migrant violence, such as the one developed by Australia, would comfortably meet the traditional criteria of gravity. This is both because of the number of victims and the vulnerability of the victims, including both refugees in general and especially children. But it is also because of the abhorrence of certain types of violence, the systematic nature of the commission of the crimes, and the involvement of high-level authorities. These elements correspond to the quantitative and qualitative criteria of gravity established in the jurisprudence. ${ }^{153}$

At the same time, the nature of migration and the violent response to it invites us to stress the criterion of impact. "Impact" is said to be considered "in light of, inter alia, the increased vulnerability of victims, the terror subsequently instilled, or the social, economic and environmental damage inflicted on the affected communities." 154 It is worth thinking about whether and how the impact of the violence of anti-migration policies is spread in a way that demands its prioritization. The often-stated goal of anti-migration is the deterrence (through effectively punitive action) of further migration, and the elimination of the so-called "pull" factors. In addition, techniques for the avoidance of responsibility are spreading across the global north. ${ }^{155}$ This points to the far-reaching impact of these potential crimes on both victims, potential victims, perpetrators, and future perpetrators. The acts of states and those they employ are crafted precisely to expand and amplify — often very far - the message that migrants are not welcome and that they can expect to suffer, should they risk the journey "north." Thinking about "impact" in this way may point us to the heart of the matter: That the violence qualified as criminal is not an incidental and regrettable, if inevitable, aspect of an otherwise legitimate sovereign policy. Instead, it is both the means and ends of the policy of deterrence, with intended results affecting not only those making the journey, but communities far beyond. Therefore, both the far-reaching impact and the claims of legitimacy and sovereign protection fueling violence against migrants, filtered and enhanced through techniques of responsibility avoidance, increase the gravity of the situation.

As is the case with the characterization of the violence against migrants as an international crime and with our understanding of the relevant actors as bearing individual criminal liability, understanding the gravity of the crimes challenges our imagination. The act of migration, in the context of ICL, invites us to flip the assumptions under which the legal regime operates-our assumptions about what a crime looks like, what a criminal looks like, and what the job of our institutions is. Benevolence, legitimacy, the prerogatives of sovereignty, all work to maintain an asymmetrical relationship, in terms of the conventional application of the categories of criminal law, in terms of where and how the law's labels are to be applied. The formal categories of the lex lata are available to apply, or develop, and potentially walk back the distance in the present relationship between migration and crime.

\footnotetext{
${ }^{152}$ Policy Paper on Case Selection and Prioritisation, supra note 118, at para. 32.

${ }^{153}$ ICC Australia Communication, at 110-13.

${ }^{154}$ Policy Paper on Case Selection and Prioritisation, supra note 118, at para. 41. See also Heller, supra note 150. Much has been made of the OTP's reference to environmental destruction and economic crimes, such as land-grabs, as indicating a more structural and dynamic understanding of the nature of crimes and their impacts. It remains to be seen what effect this will have on Persecutorial policy on case selection and prioritization.

${ }^{155}$ The Australian model has specifically inspired aspirations for emulation. See Austrian Minister wants to replicate Australian model for refugees, EuRACTIV.COM (June 6, 2016), https://www.euractiv.com/section/justice-home-affairs/news/ austrian-minister-wants-to-replicate-australian-modelfor-migrants/; Rachel Eddie, "Australia Has an Interesting Model": Danish MPs to Visit Nauru Detention Centre in the Hope it May Provide Answers to Migration Crisis in Europe, DAILY MAIL (Aug. 24, 2016), http://www.dailymail.co.uk/news/article-3756451/Danish-MPs-visit-Australia-s-detention-centreNauru.html. Beyond an exact replication of this model, what is emulated is the combination of detention, deportation and avoidance of responsibility described above.
} 
In institutional terms, this augurs for the responsibility of an international institution like the ICC to realize a more sophisticated and politically consequential understanding of the principles of complementarity and gravity enshrined in its Statute. In that process, the Court may be able to move away from its almost exclusive focus on violence perpetrated in the global south and the spaces wherefrom migration is seen to originate. For legal advocates, and those who seek to challenge both powerful actors and established understandings of international law, it may also point to some value in taking international criminal law generally, and the International Criminal Court specifically, as a serious site for engagement.

\section{E. Against the Fetishization of International Criminal Law}

The account laid out thus far has aimed to identify the potential in analyzing, characterizing and adjudicating violence against migrant-which forms part of developed states' anti-migration policies, supported by developing techniques of responsibility avoidance-through the categories and tools of ICL. The argument for such a potential is in danger of painting an uncritical picture of international criminal law and institutions as the most powerful and best set of tools to label and address the violence against migrants. In this concluding section, I wish to explore and express some counterarguments and doubts. There are two predictable mainstream critiques of the arguments presented above. The first concerns the risks to doctrinal clarity and the uniqueness of international criminal law. The second focuses on the practical unlikelihood of success of the modes of argumentation and advocacy I have presented thus far. Here, however, I want to focus on the deeper critiques that remain even if one is not compelled by these more predictable mainstream concerns. Engaging such deeper critiques is especially important when one sets out, as I have tried to do here, a "critical" approach — in its effort to make visible the power structures of Western and intergovernmental bureaucracies of management, in its manner of potentially shedding light on the political and emancipatory act of migrating.

The combination of the power of labelling, and the expansive and inherently global reach of the tools of ICL create the temptation to see it as a silver bullet. One that will reveal and recognize an increasing range of crimes, and hold accountable the most blameworthy perpetrators, especially those from wealthy and powerful states. It is a promise of vindication. The punitive imagination is a powerful thing. It allows us to project our deeply felt moral certainty, and may lull us into complacency in doing so. The recognition and exposition of the moral and political biases in the existing practices of international criminal law and punishment doesn't, by itself, justify supporting an alternative practice, even one that purports to reverse the existing bias. The danger is that both in terms of labeling and in terms of the tracing of individual and collective responsibility, an ICL practice that sees itself as critical is anything but. At the heart of this danger is daring to conceive of ICL as anything but a hegemonic governance practice of powerful actors who seek to defeat their weaker enemies in law as well as in fact.

There is a well-developed critique of criminal law as a conceptual and institutional apparatus which primarily serves the exercise of power. The recognition of who and what is criminal and their punishment uses the creation of a feeling of punitive solidarity in society to bolster those in the dominant position to control the institutions of power. ${ }^{156}$ Different facets of this critique have been applied to the existing history and institutions of ICL, ranging from the association of ICL with imperialism and capitalism ${ }^{157}$ to realist assessments of the ICC's scope of action. ${ }^{158}$ The argument is that ICL is necessarily and inescapably hegemonic. Moreover, for all its promises

\footnotetext{
${ }^{156}$ See Carvalho \& Chamberlen, supra note 40.

${ }^{157}$ See Grietje Baars, Making ICL History: On the Need to Move beyond Prefab Critiques, in CRITICAL APPROACHES TO International Criminal Law: An Introduction (Christine Schwöbel ed., 2014); Tor Krever, International Criminal Law: An Ideology Critique, 26 LeIDEN J. INT'L L. 701 (2013).

${ }^{158}$ David Bosco, Rough Justice: The International Criminal Court in a World of Power Politics (2013).
} 
to identify and link responsibility with acts, critiques of the operation of ICL and the ICC have shown that the existing regime does not reduce distance, but rather increases and imposes it. ${ }^{159}$

Can there be an ICL conceived and practiced in an anti-hegemonic manner, not reinforcing but challenging the structures of global power? Would such a practice be anything more than a momentary and low-cost protest rhetoric? Would such an application in any way survive its ambition? And could this be done in the context of the violence against migrants? This Article has attempted to relate such a vision of ICL to the migration and the violence against migrants, but has done so only at a conceptual level. Recently, the Prosecutor of the ICC, in her periodic reports on the evolution of her investigations into the situation in Libya, declared that alongside preexisting cases against the Qaddafi regime and potential cases against armed rebels, she is looking into violence perpetrated against migrants throughout the territory of Libya, and in particular in the context of detention facilities that operate therein. This has followed reports by UN Special Rapporteurs, stressing that acts of murder ${ }^{160}$ or torture ${ }^{161}$ against migrants may constitute international crimes and that, if there are reasonable grounds to believe that such crimes under the jurisdiction of the ICC have occurred, the Court should investigate. In terms of the potential perpetrators, the Prosecutor has pointed out that violations and potential crimes are committed by a complex network of actors. ${ }^{162}$ And yet, despite the well documented cooperation between European states and the Libyan Coast Guard, ${ }^{163}$ the Prosecutor's account of this network does not include such states. It may be that, despite evidence of close cooperation, the Prosecutor's view is that a legal argument of complicity is implausible and not even worthy of examination. It may also be that the stance reflects the recurring limitations of current ICL institutions. The exclusion of even the potential investigation of European actors, in any case, reinforces the powerful actors' success in the avoidance of responsibility.

But the limitations of the actually-existing ICC aside, the question remains whether marshalling international criminal law can ever be anything more than an exercise in punitive imagination or, worse, further strengthen a set of tools that do more harm than good, both in what they focus on and in what they leave out. ${ }^{164}$ Does talking about international criminal law and allowing it to capture our imagination crowd out other forms and types of legal imagination and practice, as well as political action? ${ }^{165}$ The question is rendered more poignant in the context of migration. If we recognize that the gravity of the violence against migrants is such because it reflects and is the consequence of a fundamental asymmetry of political power, punitively applied, is the attempt to flip that relationship sterile mimesis? Is throwing back the label of crimmigration to its

\footnotetext{
${ }^{159}$ Phil Clark, Distant Justice: The Impact of the International Criminal Court on African Politics (2018); Mark Drumbl, Distant Justice Symposium: Some Thoughts on Getting Close, OPINIO JuRIS (Oct. 3, 2019), http://opiniojuris.org/ 2019/10/03/distant-justice-symposium-some-thoughts-on-getting-close/.

${ }^{160}$ Agnes Callamard, Special Rapporteur of the Human Rights Council on Extrajudicial, Summary or Arbitrary Executions, Report of the Special Rapporteur of the Human Rights Council on Extrajudicial, Summary or Arbitrary Executions, U.N. Doc. A/72/335 (Aug. 15, 2017).

${ }^{161}$ Nils Melzer, Special Rapporteur on Torture and Other Cruel, Inhuman or Degrading Treatment or Punishment, Report on Torture and Other Cruel, Inhuman or Degrading Treatment or Punishment, U.N. Doc. A/HRC/40/59 (Jan. 16, 2019).

${ }^{162}$ Statement to the United Nations Security Council on the Situation in Libya, pursuant to UNSC Res. 1970 (2011) (May 8 , 2019), https://www.icc-cpi.int/Pages/item.aspx?name=180508-otp-statement-libya-UNSC.

${ }^{163}$ See, among the sources cited infra, Council of Europe Commissioner for Human Rights, Bridging the Protection Gap for Refugees and Migrants in the Mediterranean (May 2019), https://rm.coe.int/lives-saved-rights-protected-bridging-theprotection-gap-for-refugees-/168094eb87. And see Human Rights Watch, No Escape from Hell: EU Policies Contribute to Abuse of Migrants in Libya (Jan. 21, 2019), https://www.hrw.org/report/2019/01/21/no-escape-hell/eu-policies-contributeabuse-migrants-libya, especially section II.

${ }^{164}$ On the displacement theory as applied more broadly to human rights law see Paul O'Connell, Human Rights: Contesting the Displacement Thesis, 69(1) Northern Ireland Quarterly 19-35 (2018). On ICL, see Krever supra note 157. On the increasingly punitive turn of human rights, in the broad sense, see ANTI-IMPUNITY AND THE HUMAN RigHTS AgENDA (Karen Engle, Zinaida Miller \& D.M. Davis eds., 2016).

${ }^{165}$ Sarah M.H. Nouwen \& Wouter G. Werner, Monopolizing Global Justice: International Criminal Law as Challenge to Human Diversity, 13 J. INT'L CRIM. JUST. 157 (2015).
} 
enforcers at best unimaginative and at worst a betrayal of the aspiration of liberty at the heart of migration?

If one accepts the force of some of this critique of ICL, and its application to this subject matter, one would be well advised to avoid fetishizing the regime and its institutions and to temper one's aspirations and expectations, not only in terms of their pragmatic feasibility, but also in terms of their desirability. And yet, to the extent that we recognize that the categories of ICL, as legal categories but also through their role in wider lay discourse, reflect an intuition of justice and that these categories are meaningful to those fighting against anti-migration policies, ${ }^{166}$ the above critiques can benefit our practice. Punitive tools and especially those with such expressivist power should, if at all, be engaged with no illusions and with a conscious tactical and strategic understanding of the specific legal action. ${ }^{167}$ The conceptual stakes are accordingly increased, and this influences crucial factors in strategic litigation, ${ }^{168}$ such as the likelihood of success, the potential long-term consequences, the role of the action alongside different legal or political approaches, the danger of causing regressive jurisprudence or empowering political backlash.

The nature of both the tools and the subject matter ought to inform the goals of the broader engagement, beyond the political or legal success in a specific case. If punitive institutions and rules are properly understood as wielding a form of violence themselves, ${ }^{169}$ their employment can only have and be limited to insurgent or guerrilla qualities. This is especially the case as the "war," as it were, is not aiming at any particular final arrangement of punitive power. Migration will be ongoing ${ }^{170}$ and whatever the developing configuration between sending and receiving states and populations, the asymmetry of power will remain. So what is the ultimate goal, beyond the rhetorical, political or even legal success of specific tactical engagements? It is to express what needs to be protected internationally - the humanity in the migration of people-and to reveal the qualities of the growing threat. And yet, in doing this, the use of international criminal law can at best highlight the structures of asymmetry and injustice present both in anti-migration policies and in international criminal law itself.

\footnotetext{
${ }^{166}$ See Boochani, supra note 3. See also Itamar Mann, Boochani's Tribunal: Normalizing Human Degradation at Borders, JUST SECURITY (Dec. 19, 2019), https://www.justsecurity.org/67718/boochanis-tribunal-normalizing-human-degradation-atborders/; Itamar Mann, The New Impunity: Border Violence as Crime (draft on file with author).

${ }^{167}$ See Robert Knox, Strategy and Tactics, 21 FinNISH Y.B. I.L. 193 (2011).

${ }^{168}$ See Sander, supra note 39. See, more generally, Helen DufFy, Strategic Human Rights Litigation: UndERSTANDing AND MAXIMISING IMPACT (2018).

${ }^{169}$ For a classic exposition of that argument see Robert M. Cover, Violence and the Word, 85(8) YALE L.J. 1601 (1986).

${ }^{170}$ It may also intensify due to environmental factors and climate change. See JANE MCADAM, ClimATE CHANGE, FORCED Migration AND INTERNATIONAL LAW (2012).
}

Cite this article: Kalpouzos I (2020). International Criminal Law and the Violence against Migrants. German Law Journal 21, 571-597. https://doi.org/10.1017/glj.2020.24 